DIW BERLIN

Discussion Papers
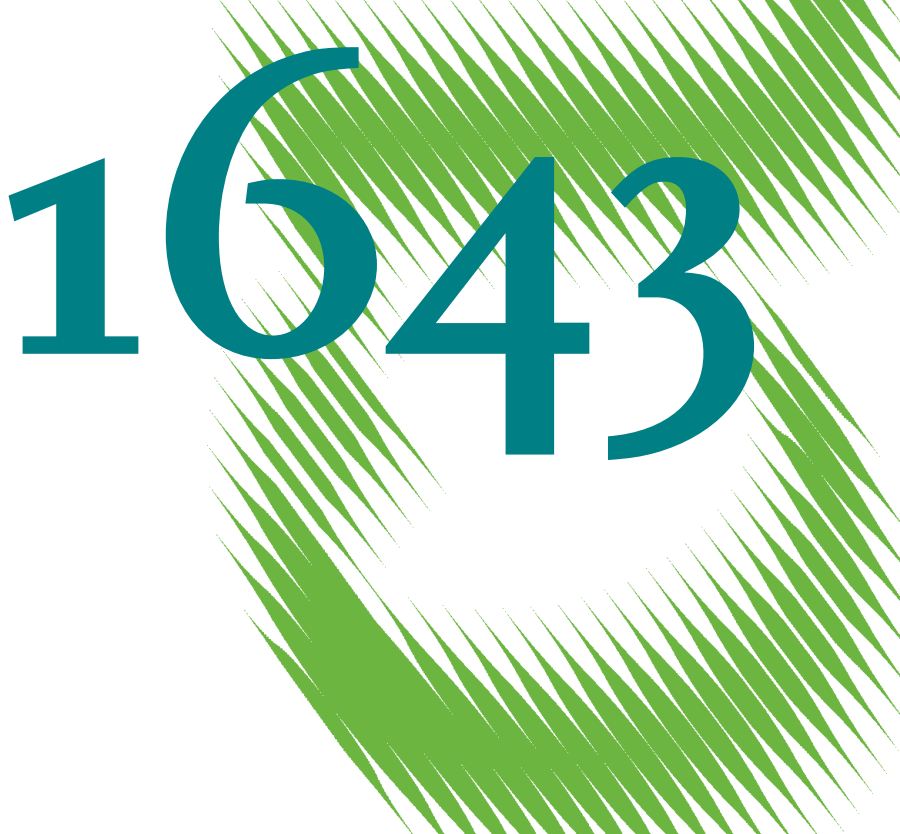

Judicial Behavior and Devolution at the Privy Council 
Opinions expressed in this paper are those of the author(s) and do not necessarily reflect views of the institute.

IMPRESSUM

(C) DIW Berlin, 2017

DIW Berlin

German Institute for Economic Research

Mohrenstr. 58

10117 Berlin

Tel. +49 (30) $89789-0$

Fax +49 (30) $89789-200$

http://www.diw.de

ISSN electronic edition 1619-4535

Papers can be downloaded free of charge from the DIW Berlin website:

http://www.diw.de/discussionpapers

Discussion Papers of DIW Berlin are indexed in RePEc and SSRN:

http://ideas.repec.org/s/diw/diwwpp.html

http://www.ssrn.com/link/DIW-Berlin-German-Inst-Econ-Res.html 


\title{
Judicial Behavior and Devolution at the Privy Council
}

\author{
Sofia Amaral-Garcia” Nuno Garoupa
}

\begin{abstract}
In this article, we study judicial behavior at the Judicial Committee of the Privy Council (JCPC). British judges in general, and British high court judges in particular, are perceived to be independent and isolated from political pressure and interference. Furthermore, these judges tend to show a particularly high rate of consensus. This has led many scholars to consider that, contrarily to what holds for several other courts around the world (such as the US Supreme Court), the attitudinal model does not find support when British higher court judges are considered. In this paper we assess whether similar conclusions might be drawn from the JCPC, another British court of last resort.

We create a unique dataset to study empirically decisions of the JCPC and investigate the extent to which judges exhibit different judicial behavior depending on the type of appeal being brought to the court, i.e., Commonwealth, devolution and domestic appeals. Our results indicate a higher polarization of judicial behavior in the context of devolution appeals (as measured by separate opinions). We discuss these results in the context of the comparative judicial behavior literature and the role of courts in the common law world (with particular reference to human rights).
\end{abstract}

JEL codes: K0

Keywords: Judicial Committee of the Privy Council, British higher court judges, judicial behavior, devolution cases, Commonwealth cases, separate opinions, human rights.

Accepted for publication in Review of Law \& Economics

We are indebted to three anonymous referees, Anthony Niblett, Jurgen Goossens, Dennis Quinn, Sung-in Jun, Ted Eisenberg, seminar participants at the Annual Conference of the International Society for New Institutional Economics (Durham, 2014), Annual Meeting of the American Law and Economics Association (Chicago, 2014), Conference of Empirical and Legal Studies (Philadelphia, 2013), ETH Zurich (Center for Law \& Economics), Spanish Law and Economics Conference (Granada, June 2013), Korean Association of Law and Economics (2013), Italian Society of Law and Economics (Lugano, 2013) and European Conference of Law and Economics (Warsaw, 2013). We are particularly indebted to Andrew Le Sueur, to the Registrar of the Judicial Committee of the Privy Council \& The Supreme Court of the United Kingdom, Louise di Mambro, and to the Head of Communications of The Supreme Court of the United Kingdom, Ben Wilson. Sóm Datye, Daswell Davis and Joanna Yu Wang have provided valuable research assistance. The usual disclaimer applies. Previous title: "Judicial Politics at the Privy Council: Empirical Evidence".

†DIW Berlin, samaralgarcia@diw.de.

Professor of Law, Texas A\&M University School of Law, USA, nunogaroupa@law.tamu.edu. 


\section{Introduction}

In comparative judicial politics, British higher court judges are considered to be independent and relatively insulated from political interference 11 Contrarily to other common law jurisdictions, the (American) attitudinal model does not find strong support when British judges are considered. In line with this approach, the rate of unanimous decisions seems considerably higher in British courts of last resort (such as the English Court of Appeal, the House of Lords Appellate Committee and the new UK Supreme Court) $\mathrm{2}^{2}$ So far, the decisions held by the British Law Lords have been essentially those studied empirically and used in more detail to test different judicial behavior theories.

Our purpose is to contribute to the literature on judicial behavior by looking at another British court of last resort, the Judicial Committee of the Privy Council (hereafter, JCPC). There are three different types of decisions that can be appealed to the JCPC: i) domestic appeals; ii) Commonwealth appeals; and iii) devolution appeals (from 1998 to 2009) ${ }^{3}$

Domestic appeals can be from ecclesiastical courts and other ancient courts, from the Disciplinary Committee of the Royal College of Veterinary Surgeons, the Professional Conduct Committee of the General Medical Council, and the Professional Committee of the General Dental Council.

Commonwealth appeals are from commonwealth jurisdictions and the vast majority of cases disposed by the JCPC refer to this type of appeal (including Crown dependencies and overseas territories) $4_{4}^{4}$ In particular, the JCPC decides on the basis of national (Commonwealth member) law. In fact, Voigt, Ebeling, and Blume (2007) do mention judicial activism in this context but suggest that it is unrelated to local politics, either of the UK (because of limited jurisdiction) or Commonwealth members (because of distance from local concerns). Furthermore, since the 1960s, Commonwealth appeals seem to be dominated by business law and protection of

\footnotetext{
${ }^{1}$ See, among others, Salzberger and Fenn (1999), Hanretty (2013), Massie et al. (2014)and references herein.

${ }^{2}$ See Hanretty (2013). When considering some common law courts of last resort (UK, India, USA, Canada and Australia), only India has higher levels of consensus. Hanretty (2013) notes that the Indian Supreme Court judges face much higher caseload.

${ }^{3}$ These devolution appeals can find some resemblance with the complaints concerning the competence of devolved legislatures under the Government of Ireland Act 1920.

${ }^{4}$ See, for instance, Keith (2009).
} 
property rights.5

Devolution appeals arose after the Scotland Act 1998, the Government of Wales Act 1998, and the Northern Ireland Act 1998. Since then, cases concerning the extent to which the devolved governments or legislatures went beyond their powers can be appealed to the JCPC.6 This type of disputes make up a small number of cases decided by the JCPC, but the decision is binding even on the House of Lords Appellate Committee 7 Such jurisdiction was lost to the new UK Supreme Court in 2009.8 Le Sueur (2001) provides some reasons for why the JCPC was chosen to hear these appeals, namely its experience on constitutional matters for several Commonwealth dependencies and colonies. Moreover, as the author describes, the Appellate Committee of the House of Lords was regarded as inappropriate given that it was in fact part of the UK Parliament, which could raise some conflicts of interest (i.e., it could lack the objective independence to deal with division of power disputes; and the same judges that previously decided the case (or were involved in the approval of the disputed legislation) could be also sitting on appeal) $9^{9}$ Therefore, the JCPC was seen as the appropriate court to deal with division of powers in terms of constitutional adjudication.

Devolution appeals are significantly important. First, they address the balance of power between the central government at Westminster and the devolved administrations (although, as it becomes clear when analyzing our dataset, the balance of powers is mostly and more specifically on human rights). Second, they effectively limit the competences of higher courts such as the High Court of Justiciary, which is the last court of appeal for criminal law in Scotland 10 Third, they have also allowed the House of Lords to be bypassed in human rights appeals when they are claimed within a devolution appeal. As a matter of fact, appeals to the JCPC between 1998 and 2009 raising devolution issues have relied on the European Convention on Human Rights (hereafter ECHR), the vast majority concerning Article 6 of the Convention. ${ }^{11}$ Finally,

\footnotetext{
${ }^{5}$ See Voigt, Ebeling, and Blume (2007).

${ }^{6}$ See, among others, Paterson (2013) and Delaney (2013). Since the Constitutional Reform Act of 2005, if not earlier, devolution appeals can be seen as cases of constitutional adjudication (given the commitment to create a new Supreme Court).

O’Neill (2004).

${ }^{8}$ For a description of the process that lead to the creation of the UK Supreme Court, see Le Sueur (2009).

${ }^{9}$ Incidentally, this was one of the major arguments for the 2005 constitutional reform that created the Supreme Court of the United Kingdom.

${ }^{10}$ See O'Neill (2001).

${ }^{11}$ See, e.g., Paterson(2013) and O'Neill (2001). Moreover, notice that ECHR rights were "brought home" into
} 
devolution appeals have, in practice, empowered English judges to influence Scottish law on human rights (not surprisingly, Scottish judges have dominated important panels at the JCPC ${ }^{12}$ integrating and applying the ECHR under Scotland Act 1998). In practice, members of the JCPC will decide Scottish criminal cases as long as human rights issues are raised ${ }^{13}$ Therefore, English judges are effectively allowed to influence Scottish criminal cases even though Scottish criminal law is perceived to be considerably different from English criminal law

Concerning control over its docket, the JCPC has limited control (at least, for American standards). For example, in the context of Commonwealth appeals, the JCPC enjoys some discretion in accepting a direct appeal only in situations where a potential appellant fails to be granted a leave of appeal from a lower court (the acceptance or rejection will be based on some general or important principle of law or wide interest standard) 15

JCPC panels are generally composed of judges with different backgrounds: the vast majority are British judges that have a judicial training and practiced in England and Wales, Scotland or Northern Ireland and can sit in any type of appeals; a minority is composed by judges that practice in Commonwealth jurisdictions and can sit in Commonwealth and domestic cases ${ }^{16}$ In this setting where judges with different backgrounds are put together to decide appeals, different judicial behaviors might emerge. Generally speaking, one might think that British judges feel more distant from Commonwealth cases in comparison with domestic and devolution cases, while judges practicing in Commonwealth jurisdictions might relate more to these decisions. Moreover, considering that devolution cases put together British judges and judges from the devolved jurisdictions, more disagreement among those judges might be expected given the nature of the decision to be made. At the same time, if a strong norm of consensus holds for the JCPC, it might prevent the observation of possible disagreements among judges.

In this paper, we study empirically the decisions of the JCPC and investigate the extent to

domestic law (i) by the Human Rights Act 1998 for UK and English public authorities and (ii) by the Scotland Act 1998 for the Scottish Government and Scottish Parliament. See Le Sueur (2001) for more on this point.

${ }^{12}$ Le Sueur (2001). See also Paterson (2013) and Munday (2002).

${ }^{13}$ See Le Sueur (2001) and Paterson (2013).

${ }^{14}$ See R. v. Manchester Stipendiary Magistrate, Ex Parte Granada Television Ltd. [1999] UKHL 51, where Lord of Craighead notes that "although there is now much common ground between England and Scotland in the field of civil law, their systems of criminal law are as distinct from each other as if they were two foreign countries".

15 Voigt, Ebeling, and Blume (2007).

${ }^{16}$ See, among others, Munday (2002). 
which judicial preferences are more likely to interfere with the law in the area of devolution than other areas of the law. In order to test this hypothesis, we consider the individual votes of judges in the context of panel decisions. We are mainly interested in assessing whether or not judges are more likely to write separate opinions in devolution cases ${ }^{17}$

We construct a unique dataset of 341 decisions from 1998-2011. As far as we are aware of, this is the most extensive dataset of JCPC decisions. Devolution cases seem to be the type of decision more prone to separate opinions: $87 \%$ of devolution appeals have at least one separate opinion. We also consider the area of law under which the appeal is brought (such as human and constitutional rights, business law and criminal law). When regression analysis is performed, we find that separate votes are more likely to be made in devolution cases, a result that is robust across different specifications. With respect to the area of law, Commonwealth appeals related to rights seem to be those showing a higher polarization of judicial behavior. However, the effect no longer holds when more controls are added. We discuss these results in the context of the comparative judicial politics literature and the role of courts in the common law world.

The paper goes as follows. In Section II, we describe the JCPC. In Section III, we discuss judicial behavior. In Section IV, we present the dataset and empirical strategy. In Section V, we address the main results. Lastly, Section VI concludes the paper.

\section{The Judicial Committee of the Privy Council}

The JCPC is a particular type of court of justice. Indeed, Le Sueur (2001) observes that ' $[n]$ obody starting with afresh would design a court that looks like the Judicial Committee of the Privy Council'. Even though the role of the Privy Council goes back to the time of the Tudors, the JCPC was formally created in 1833 (by the Judicial Committee Act 1833). There are several characteristics that make the JCPC an unusual type of court and that have to do with the type of cases this court hears, the "appointment" mechanism of judges (or lack of such a formal mechanism), the extensive number of judges that are eligible to sit in a case, and the fact that the judges that sit

\footnotetext{
${ }^{17}$ Therefore, our aim is to contribute to the empirical literature on this topic. The legal scholarship on the JCPC and UK judges is quite vast. We refer to Munday (2002), Le Sueur (2001 and 2009), Paterson (2009), Swinfen (1987), Keith (2009), Lee (2011) as extensive legal works on this subject.
} 
at the JCPC spend the majority of their time deciding cases in another court.

Formally speaking, the JCPC does not really pronounce decisions but an advice to an appeal to the monarch who, as matter of convention, accepts it. ${ }_{18}^{18}$ However, in practice, the JCPC operates as a court of appeal ${ }^{19}$ The advice provided by the JCPC is subject to standard appellate proceedings, there are formal legal and procedural rules, and the decision is binding on both parties. The JCPC deals with points of law, and facts are not formally reviewed. Since 2007, the JCPC has had the power to depart from precedent if needed 20

There are different judges on the JCPC: the Law Lords, that is, the judicial members of the House of Lords before the 2009 changes that lead to the creation of the UK Supreme Court (known formally as Lords of Appeal in Ordinary, and the British equivalent of the US Supreme Court justices; these are now the UK Supreme Court Justices); senior judges from the UK (other Lords of Appeal); privy counsellors with judicial background (judges from the Court of Appeal of England and Wales, the Inner House of the Court of Session in Scotland and the Court of Appeal in Northern Ireland); other privy counsellors who are senior judges abroad (usually judges from superior courts of Commonwealth members); and the Lord Chancellor (before the Constitutional Reform Act 2005) ${ }^{21}$ There is no formal selection procedure for judges to be appointed to the JCPC. Essentially, judges of certain seniority who are appointed to other courts become eligible to sit on the JCPC, which works as a sort of part-time court. More than sixty judges are eligible to be called upon and decide cases at the JCPC. Voigt, Ebeling, and Blume (2007), citing Beth (1975), consider the process to be functionally apolitical since the privy counsellors do not rule extensively on domestic constitutional law in the UK. They also suggest that the potentially most politicized members, the Law Lords, might be in the minority given the composition of the JCPC (although recognizing they do most of the relevant work) ${ }^{22}$

\footnotetext{
${ }^{18} \mathrm{~A}$ fiction to be removed when appeals are from Commonwealth republics, a principle reformed in 1957 to allow appeals from Malaysia. They are appeals to His/Her Majesty in Council. In the case of Brunei, the JCPC formally reports an opinion to the Sultan.

${ }^{19}$ See, for instance, Munday (2002).

${ }^{20}$ See Abbott v Abbott [2007] UKPC 53, delivered by Lady Hale, at [3] and [19]. Moreover, in the JCPC there was only one opinion allowed until 1966 when the Australians insisted that dissents should be allowed (see e.g. Alder (2000) at p. 236; Keith (2009), p. 320; Munday (2002); or Swinfen (1987), p. 222). The possibility of concurring was not mentioned by then, and it was not until 1999 that judges sitting at the Privy Council are allowed to deliver individual concurring judgments (Munday (2002), p. 622).

${ }^{21}$ Therefore, the difference in the current composition of the JCPC is that the Law Lords are now Justices of the Supreme Court of the UK, and that the Lord Chancellor is no longer part of it.

${ }^{22}$ However, our dataset indicates the Law Lords dominate the court panels.
} 
The JCPC usually sits in panels of three or five judges, the general rule being that the board should have an odd number of judges ${ }^{23}$ The composition of judicial panels that dispose cases at the JCPC differs between Commonwealth and devolution appeals. For the latter, only certain privy counsellors are eligible. More precisely, only judges with a high judicial office under the Appellate Jurisdiction Act 1876 or House of Lords judicial members (i.e., British senior judges) can sit in devolution appeals. ${ }^{24}$ Inevitably, Commonwealth judges were excluded and, by default, devolution cases were largely disposed by a panel largely dominated by Law Lords.

In an earlier study of JCPC devolution cases, O'Neill (2001) observed that decisions seem to be unanimous, deferent to the Crown rather than to the lower court (in fact, reversing decisions if and when needed), and sensitive to the presence of influential jurists (mentioning the preponderance of Scottish judges). ${ }^{25}$ While Voigt, Ebeling, and Blume (2007) praise the JCPC for delivering impartial, independent, and high quality decisions in the context of Commonwealth appeals, O’Neill (2001) identified a process of increasing judicial politics when the court addressed devolution cases. Still, the possible patterns of judicial politics at the JCPC changed from the early work of O'Neill (2001). When we look at all cases (and excluding commonwealth appeals), the Crown still won a majority of the cases and separate opinions become more common (very much as they did in the House of Lords in the same period).

One particular aspect that has deserved attention is the sensitivities raised by Scottish appeals to either the House of Lords or the JCPC (see, generally on Scottish Appeals, Brodie (2009), Walker (2010), Paterson (2013)). For instance, Walker (2010) mentions that, from a historical perspective, Scottish litigants were not barred from appealing to the House of Lords, a provision that intended most likely to mitigate Scottish sensitivities "concerning the prospect of domination by English institutions". In fact, the connection between the final court of appeal and the Scots has sometimes been a tense one 26

\footnotetext{
${ }^{23}$ See Patterson (2013) for panels at the House of Lords. Moreover, as the author argues, there is some suggestion that the larger the panel size in which the judges of the final appeal court sit, the greater potential for concurring or dissent opinions. We test for this hypothesis in the empirical analysis. ${ }^{24}$ Le Sueur (2001).

${ }^{25}$ In other words, the inference (based on an article by O'Neil) is that the judges were involved in judicial politics (within the JCPC) in devolution cases within the court and often deferent to the Crown. Notice, however, that O'Neill was writing when only four of the 23 devolution cases had been decided.

${ }^{26}$ See Paterson (2013), Walker (2010) and Brodie (2009). From a historical perspective, not even the arrival of Scottish judges in London satisfied the legal nationalists (i.e., those committed to retaining the purity of Scots law free from external influence, in particular from English influence).
} 


\section{Judicial Behavior}

\section{III.1 General Theory}

There is vast literature on judicial behavior. Different theories have been developed, mainly in the context of the United States, to explain how judges behave and why they decide cases in a certain way. In this respect, there is an important ongoing debate over whether judges are guided solely by the law, solely by their personal ideology, or by a mixture of the two. Formalists or legalists argue that judges simply interpret and apply the law in a largely conformist view of precedents. In other words, judges are fundamentally guided by what the law says and abide by a strict legal authoritative interpretation. The so-called attitudinal model sees judicial preferences, with special emphasis on ideology, as the main explanatory model. Finally, agency theorists propose the strategic model according to which judges behave strategically in the sense of anticipating other actors' responses. Judges give their best response to the other actors decisions, which means that they might not vote for their most preferred option. While recognizing the importance of judicial preferences, the model also emphasizes political and institutional realities 27

In general, judges have to weigh their individual preferences (their disposition towards a particular outcome) and their influence on the decisions of the court (their ability to shape the outcome in terms of public policy) ${ }^{28}$ Individual policy preferences are associated with the court's opinion while dispositional preferences reflect an ideal position associated with an individual judge's opinion. In collegial courts, judges have to trade policy losses (whether or not an individual judge supports the court's opinion) against dispositional losses (whether or not an individual judge delivers an opinion consistent with the most preferred solution). Policy losses are determined by the interaction between judges while dispositional losses are independently determined by each individual judge. While the attitudinal model focuses on dispositional losses, the literature on strategic judicial decision-making takes into account both policy losses and dispositional losses.

\footnotetext{
${ }^{27}$ For discussion, see Brenner and Spaeth (1988), Segal and Cover (1989), Gely and Spiller (1990), Epstein and Knight (1998), Segal and Spaeth (2002), and Hansford and Springgs II (2006), among others.

${ }^{28} \mathrm{See}$ Cameron and Kornhauser (2010).
} 
These different theories of judicial behavior cannot be extensively addressed without an adequate empirical assessment and evaluation. Legal scholars and political scientists have naturally focused much empirical attention on the US Supreme Court. ${ }^{29}$ Empirical debate about other higher courts is an emerging literature, with notable applications in Europe and North America $\sqrt{30}$, in Asia 3 , and in Latin America 32

In Britain, traditionally, the general view has been that judges do not decide cases politically ${ }^{33}$ There is however some evidence that judges might take into consideration other factors when making decisions. For instance, some Law Lords might be more likely to vote in favor of the state than others ${ }^{34}$ More interestingly, especially when studying decisions from the House of Lords Appellate Committee, Hanretty (2013) points to the fact that variations in ideal points can be better explained by differences between Scottish and non-Scottish judges rather than by political party. Arvind and Stirton (2012) noticed that the Law Lords are more polarized than the traditional account suggests, but not on ideological grounds. They find significant variations on the estimated ideal points when considering human rights cases, but the explanation seems more related to background and other cultural factors as opposed to political determinants. As Hanretty (2013) described, when compared to higher courts from different countries, the levels of dissent by British judges is relatively low (in comparison with Canada, Australia and US; only India presented higher rates of consensus than the UK). Moreover, the author argues that

\footnotetext{
${ }^{29}$ See Brenner and Spaeth (1988), Segal and Cover (1989), George and Epstein (1992), Epstein and Knight (1998), Epstein, Segal, and Spaeth (2001), Segal and Spaeth (2002), Goff (2006), Hansford and Springgs II (2006), and Lax and Cameron (2007).

${ }^{30}$ On Canada, see Tate and Sittiwong (1989), Alarie and Green (2008), Green and Alarie (2009), and Songer, Szmer, and Johnson (2011). On Germany, see Schneider (2005) and Vanberg (2005). On Italy, see Breton and Fraschini (2003), Fiorino, Padovano, and Sgarra (2007), Padovano (2009) and Dalla Pellegrina and Garoupa (2013). On Portugal, see Amaral Garcia, Nuno, and Grembi (2009). On France, see Franck (2009) and Franck (2010). On Spain, see Garoupa, Gili, and Gómez-Pomar (2012) and Garoupa, Gómez-Pomar, and Grembi (2013). On Israel, see Shachar, Gross, and Harris (1997), Eisenberg, Fisher, and Rosen-Zvi (2011) and Eisenberg, Fisher, and Rosen-Zvi (2013). On Australia, see Smyth and Narayan (2004).

${ }^{31}$ On Japan, see Ramseyer and Rasmusen (2003), and in particular on the Japanese Supreme Court, see Ramseyer and Rasmusen (2006). On Taiwan, see Ginsburg (2003), Garoupa, Grembi, and Lin (2011) and Dalla Pellegrina, Garoupa, and Lin (2012). On the Philippines, see Escresa and Garoupa (2012).

${ }^{32}$ On Argentina, see Chávez (2004) and Helmke (2004) as well as Iaryczower, Spiller, and Tommasi (2002) and Iaryczower, Spiller, and Tommasi (2006). On Chile, see Hilbink (2007) and Carroll and Tiede (2011). More generally, see Kapiszewski and Taylor (2008).

${ }^{33}$ See Hanretty (2013). More recently, different views with respect to judicial appointments, in particular for top courts, have been proposed. Still, in practice, until quite recently, there has been a high degree of homogeneity along several judges' characteristics, such as social background and career patterns. See Malleson (2009) and Griffith (1997).

${ }^{34}$ Robertson (1982).
} 
'the British constitution offers few opportunities for policy-seeking judges' than other common law jurisdictions.

There is an extensive discussion on British judges' approach to multiple judgments. During a debate held in 2008 and described by Le Sueur (2008), Law Lords, Lord Justices and other members of the judiciary, academics and legal practitioners discussed whether the UK Supreme Court should have concurring or dissenting opinions. As described by Le Sueur, the issue of dissenting or concurring opinions has been discussed for many years in the UK and the arguments presented in favor and against single judgments should be well-known by now. The existence of multiple judgments is perceived to enrich the legal system, support judicial independence. Single judgments tend to "drab and lack individuality" (Le Sueur, 2008). As described additionally, forcing a Law Lord to agree with their colleagues can lead to frustration and unhappiness, as these judges should be motivated for writing judgments. Another prevailing view is that concurring and dissenting opinions should be given only in case there is something different to say (Le Sueur (2008) and Paterson (2013)).

In line with this discussion lies the debate on the importance of concurring opinions. One might ask whether concurring opinions are relevant, considering that they essentially agree with the final outcome of the decision. Lee (2009) contends that concurring opinions can indeed enhance the value of the decision for different reasons, namely by buttressing the lead judgment from dissenters, agreeing with outcome while disagreeing with the reasons, mediating between differing lead judgments and providing greater accessibility of the decision to the general public. Munday (2002) argues that concurring judgments can be difficult to characterize but that they are a more intense form of judicial self-expression. As the author puts it, "concurring speeches are a reminder that within a common-law system, where the judges fashion the law (...) cases are not just about outcomes. Litigation is not simply a form of dispute settlement, for its own sake. It matters how a solution is arrived at". Moreover, this type of decisions is relevant for keeping the system honest. 


\section{III.2 Can Devolution cases induce different judicial behavior?}

In a model of judicial politics, separate opinions are expected to the extent that they express different ideological or philosophical views of the world either merely attitudinal or strategic. However, there are significant limitations to systematic and generalized separate opinions. First, judges have a degree of dissent aversion for various reasons, including the additional work that dissenting requires, the difficulties of collegial relationships or their detrimental effects on the workplace ${ }^{35}$ Concurring opinions are likely to be less costly but still require additional judicial resources. A second limitation is the nature of the case - the extent to which there is no discretion according to the law. Alternatively, not every case can generate creative and distinct legal arguments as to justify separate opinions. A third limitation is the tradition of the House of Lords Appellate Committee to avoid exhibiting differences across the bench: ${ }^{36}$ in particular, the concern that any degree of politicization can be perceived by the general public. In fact, Arvind and Stirton (2012) argue that there is a strong norm for consensus and deflection of possible signs of division ${ }^{37}$

While looking at decisions made by the JCPC, there is a strong distinction among types of cases (i.e., devolution, Commonwealth or domestic appeals). Nevertheless, it is also important to take into account the area of the law that the case refers to. While devolution appeals seem to be related exclusively to conflict of executive powers, they are fundamentally (but not only) cases that affect human rights, which can raise two possible effects. On one hand, rulings in devolution cases are relatively more important because it is a new area of the law dealing with difficult issues of human rights. It could be argued that such cases require stronger precedent and therefore fewer separate opinions should be observed. On the other hand, since devolution appeals are the only cases of a political nature that are directly related to the members of the court (privy councillors have few opportunities to deal with UK constitutional law), we may expect more legal debate and enhanced expressive roles. At same time, judges could be more

\footnotetext{
${ }^{35}$ See Epstein, Landes, and Posner (2011) and Edelman, Klein, and Lindquist (2012).

${ }^{36}$ Jones (1982) and Hanretty (2013).

${ }^{37}$ Lord Kerr of Tonaghmore (2012) describes that the small number of dissents among British judges may be attributed in part to the value placed on the oral tradition. He also adds that dissents do not affect the cordial relations that exist among his colleagues. Additionally, while Lord Neuberger (2012) presents some reasons why concurring and dissenting opinions might be valuable, he also proposes them to be shorter and less frequent.
} 
concerned with their performance and therefore develop more careful separate opinions in order to establish their individual legitimacy.

While dissents can be perceived as ideological polarization when it comes to constitutional law, concurring opinions should be regarded as individual contributions to the development of mature legal doctrines ${ }^{38}$ It is likely that devolution might deter dissents (in order to create strong precedent) while inducing additional concurring opinions (so that individual judges can be regarded as making significant legal contributions).

Devolution appeals to the JCPC can be regarded as a mechanism to bypass the absence of a right of appeal to the House of Lords Appellate Committee from the Scottish High Court of Justiciary. As such, judges could feel pressured to provide more detailed and lengthy arguments so as to avoid a generalized appeal mechanism. Concurring opinions are likely to be the appropriate tool to balance two opposing goals: deciding important criminal cases while not undermining significantly constitutional design.

To some extent, devolution cases at the JCPC can be understood as similar to human right appeals at the House of Lords Appellate Committee. They are of constitutional importance and, being quite new, demand the development of legal doctrines that inevitably shape British law. Arvind and Stirton (2012) already shown that the Law Lords are divided when it comes to ruling on human rights. A possible inference is that we should find a similar result with devolution cases in the Privy Council (furthermore, when many of the individual judges are the same).

Concerning domestic and Commonwealth cases, we expect fewer separate opinions in cases that are not related to human rights. Domestic cases are relatively marginal since they are appealed from a limited number of bodies and the vast majority concerns professional misconduct cases. As for Commonwealth cases, they do not satisfy the conditions we have discussed. They are unrelated to UK human rights, British constitutional law or policy issues. At the same time, they require the application of Commonwealth law which is likely to demand less interest and concern by UK senior judges; the expressive role of the British judiciary in developing Commonwealth law is plausibly weak. A possible difference might be in Commonwealth cases involving

\footnotetext{
${ }^{38}$ See Lee (2009). Moreover, Hettinger, Lindquist, and Martinek (2003) suggest concurring opinions 'serve important functions as they disclose inconsistencies in the law or highlight a legal doctrine ripe for overruling.' They also argue that concurring opinions could be 'potential whistle-blowing devices' when reflecting agreement over the outcome but not on the legal grounds.
} 
human rights, if indeed there is a difference in judges' behavior when it comes to human rights cases in general, even when they are brought under Commonwealth. In some Commonwealth jurisdictions, sentenced criminals might be sent to death, which can raise contentious issues. Moreover, there could be some concern that plaintiffs might be sentenced to jail without the right to a fair trial. Therefore, on the one hand privy counsellors might feel distant to cases raising human rights issues when they originate from Commonwealth jurisdictions. On the other hand, judges might want to express their views on these cases, given that they can bring serious human rights concerns. In this setting, if a separate opinion is given in a Commonwealth case, it is more likely that it will be a dissent. Precisely because the judges deciding the case are less concerned about how the law will be applied in the country of origin, they may be less worried about sending a sign of possible divisions (in which dissent is a stronger sign of division than separate opinions). Unless we assume some extreme context; for example, judges might be worried that Commonwealth states use possible court divisions as a possible justification to exit JCPC jurisdiction ${ }^{39}$

\section{III.3 Determinants of Separate Opinions}

Besides a possible different judicial behavior concerning devolution cases or cases involving rights, when can we expect to find judges being more prone to write separate opinions at the JCPC? Considering that writing separate opinions are costly, namely due to the additional time required to write them, the judges that have more resources available are those that should have, in principle, a lower cost. At the JCPC, these judges are the Law Lords, given that they can be supported by judicial assistants and share resources from the court 40

With respect to judges' seniority, senior judges might be more willing to present separate opinions in comparison with more junior judges. Senior judges have acquired a long practice over the years and have more experience to call upon, while more junior judges might prefer

\footnotetext{
${ }^{39}$ At least according to some anecdotal evidence, this does not seem to be the case. For instance, http://www . bbc.co.uk/caribbean/news/story/2009/09/090922_privyccjphillips.shtml last access on 30 June, 2014.

${ }^{40}$ Although retired judges might have advantages in another important resource, namely, available time. Additionally, the Law Lords could eventually have some "institutional memory" that makes them more likely to write separate opinions. The reason is that the House of Lords abandoned considerably late the practice of delivering opinions seriatim. We acknowledge this point made by an anonymous referee
} 
not to disagree with their senior colleagues. ${ }^{41}$ Moreover, as judges approach their retirement age they might be called to sit in a lower number of cases, which would give them more time to devote to each decision and to write separate opinions.

In an in-depth analysis of the Law Lords and the Supreme Court, Paterson (2013) points to the fact that there might be differences in terms of the Senior Law Lord's attitudes with respect to single majority judgments. During our period of analysis there were three different Senior Law Lords: Lord Browne-Wilkinson (1998-2000), Lord Bingham of Cornhill (2000-2008) and Lord Philips (2008-2009). Lord Philips was the last Senior Law Lord before the creation of the UK Supreme Court, and also the founding president of the Supreme Court. For instance, Lord Bingham is held as one Senior Law Lord particularly sympathetic with multiple judgments (Le Sueur (2008) and Paterson (2013)). Given the evidence that the Senior Law Lord may have an important role when it comes to judges' opinions, we include this insight in the empirical analysis as well.

The different backgrounds of judges taking part in decisions at the JCPC could also play a role. All in all, the JCPC puts together Scottish judges, English and Welsh judges, Northern Irish judges and judges from Commonwealth jurisdictions. We should expect that it is more costly for a UK judge to decide a case based on Commonwealth law, given that he must know the law from the originating jurisdiction. As for devolution cases, and considering that Commonwealth judges are not allowed to sit on these cases, it should represent a higher cost for an English judge to decide on a Scottish criminal case. As mentioned before, there are significant differences between England and Scotland in criminal law: in practice, it works as if they were two foreign countries. In fact, there is some discussion on how interventionists can non-Scottish Law Lords be in Scottish cases. One possible view is that non-Scottish judges tend to be deferent to Scottish judges in Scottish cases because they perceive their colleagues to be specialist of the field. In order to investigate the deference critique further, Paterson (2013) considers the percentage of Scottish judges taking part in Scottish cases (at the Privy Council, House of Lords and the Supreme Court). The author claims that when important factor are considered, the deference

\footnotetext{
${ }^{41}$ Indeed, there seems to be some concern that more junior judges could be deferential to their more senior colleagues. Therefore, the tradition at the first conference at the House of Lords and the Privy Council has been to work in the inverse order of seniority (Paterson (2013)). Hence, seniority can have a role and we control for it in the regression analysis.
} 
theory does not hold. One important fact is that many of the Scottish appeals are not related to Scottish common law. Another is the panel composition and whether Scottish judges are in minority, a factor we take into consideration in the empirical analysis.

The functioning role of the JCPC as a part-time court might eventually lead to differences in judicial behavior as well. On the one hand, we may observe less separate opinions precisely because judges prefer to allocate less time to JCPC appeals while spending more time on the appeals from the court where they spend the majority of their working time. On the other hand, and precisely because there is no perfect overlap between judges' colleagues at the JCPC and judges' colleagues at their "full-time court" ${ }^{42}$ judges might feel more free to give their sincere opinion if they do not fully agree with their colleagues. Moreover, even if there is a strong norm of consensus among British higher courts of justice, the part-time role of the JCPC might make this norm less salient.

\section{Data and Empirical Strategy}

We collected data on JCPC appeals from 1998-2011 43 From a total of 828 decisions 44 during this time period, 23 correspond to devolution appeals, 96 to domestic appeals, and 709 to Commonwealth appeals. Our sample is composed by all devolution cases (23 case), all domestic cases (96 cases), all Commonwealth cases with separate opinions (63 cases), and a random sample of Commonwealth cases without separate opinions (159 cases) ${ }^{45}$ Overall, our sample is composed by 341 decisions, which represent $41 \%$ of the court decisions in the analyzed period. As we can see in Table 1, 20 cases out of 23 devolution cases had separate opinions (87\%). If we consider the total of 96 domestic cases, the same took place in only one case. As for Commonwealth cases, 63 decisions out of 222 had separate opinions (28\%) ${ }_{46}^{46}$ Clearly, devolution

\footnotetext{
${ }^{42}$ Even if one considers judges from the Supreme Court, there are many more judges that can be called to sit at the JCPC.

${ }^{43}$ Although the JCPC lost jurisdiction concerning devolution cases to the UK Supreme Court in 2009, we include decisions until 2011 to make sure that there are no further differences between Commonwealth and domestic appeals. In the appendix, we include robustness checks in which we exclude cases decided in 2010 and 2011.

${ }^{44}$ We excluded two hearings, given that this type of decision was not relevant for our study.

${ }^{45}$ We account for the sampling method in the regression analysis, where we attribute weights to the cases according to the probability of being sampled.

${ }^{46}$ The 63 decisions with separate opinions are out of a population of 709 Commonwealth decisions (9\%).
} 
cases present the highest level of separate opinions. In domestic cases, separate opinions are virtually non-existent (only one case out of 96).

As summarized in Table 2, the dataset includes 1,517 individual votes, with 109 referring to devolution cases, 294 to domestic appeals, and 1,114 to Commonwealth appeals. When we exclude the judge delivering the majority opinion 47 the total number of individual votes is 1,172 . There are 203 individual votes with separate opinions (around $13 \%$ of the dataset), and devolution cases have 78 votes with separate opinions (72\%, overwhelmingly concurring opinions), domestic cases have one vote with a separate opinion, and Commonwealth appeals have 124 individual votes with separate opinions (11\%, a majority of dissents and a minority of concurring opinions). What this table also shows is that although British-Non-Scottish votes account for a significant majority of total votes, votes made by Scottish judges presented a slightly higher proportion of separate votes. Overall, $14.3 \%$ of Scottish votes had a separate opinion, while $13.6 \%$ of British-Non-Scottish votes had a separate opinion.

Table 3 defines the variables we collected concerning different characteristics of the cases, the nature of the appellant and respondent, and judges attributes. Table 4 presents the summary statistics for these variables per decision (341 decisions), per judge (68 judges) ${ }^{48}$ and per individual vote (1,517 votes). We consider which judges take part in the decision, the judge writing the opinion for the majority, whether the judge was a Law Lord, whether the judge had practiced in the Scottish jurisdiction, whether the judge is in majority in the panel (i.e., if the judge is Scottish and the majority of the panel is composed by Scottish judges, or if the judge is English and the majority of the panel is composed by English judges), and whether the judge delivering the decision is from the originating jurisdiction of the case. ${ }^{49}$

Our empirical strategy consists on assessing whether different types of cases (in particular, devolution cases) can be associated with distinct judicial behavior as measured by separate opinions 50 Therefore, we want to test the hypothesis that the likelihood of having separate

\footnotetext{
${ }^{47}$ The judge delivering the majority opinion can never present a separate opinion. We consider the author judge as being the main judge delivering the leading opinion.

${ }^{48}$ Information about all sixty-eight judges is presented in Appendix, including total votes, separate opinions in the dataset and other characteristics.

${ }^{49}$ It is important to notice that panel composition is rarely repeated (from a total of 341 decisions, there were 296 different panel compositions). For panel decisions on US circuit courts, see Fischman (2013).

${ }^{50}$ In regressions not reported here we also test whether devolution cases are lengthier (measured by the total number of words in the decision). The rationale is that the length of a decision can be seen as a proxy for case
} 
opinions is higher in devolution cases when compared to domestic and Commonwealth cases.

We start by estimating a logit model that examines the relationship between separate opinions and both judge and case characteristics. For each judge individual vote, our model is of the form:

$$
\text { separate }_{j i}=J U D G E_{j i}+C A S E_{i}+\eta_{t}+\epsilon_{j i}
$$

The variable separate $_{j i}$ is a dummy equal to one if judge $j$ presented a separate opinion in case $i$. By definition, separate $_{j i}$ is always zero for the judge writing the leading opinion. Therefore, we exclude the judge delivering the opinion from the regression, but include informative variables about this judge ${ }^{51} J U D G E_{j i}$ is a vector with judge-specific controls that includes an indicator for the judge being Scottish, an indicator for the judge being female, an indicator for the judge being a Law Lord, and a variable that quantifies how many years are left until the judge's retirement. $C A S E_{i}$ includes information on the case being decided, panel composition and author judge's controls. It includes the type of appeal, a variable with the panel size, and indicators for the original jurisdiction of the author judge, the judge being in majority in the panel, the author judge being from the same jurisdiction that the originating case jurisdiction, the judge being from the same jurisdiction that the case origin, and the judge being from the same jurisdiction that the author judge. $\eta_{t}$ is years fixed effects and $\epsilon_{j i}$ is an error term.

We take into account the sampling method used to obtain our dataset, more specifically, to obtain the random sample of cases that were drawn from unanimous Commonwealth cases. In order to do so, we use survey commands that allow the inclusion of different weights according to the probability of a case being sampled $[52$ In some regressions, we account for both the sampling method and for the panel size in the decision.

In addition to the model described above we also estimate a model that uses the proportion

difficulty (Epstein, Landes, and Posner $(2011))$. We did not find that devolution cases have lengthier opinions, which seems to suggest that devolution cases are not more difficult to decide than Commonwealth cases. Results are available upon request.

${ }^{51}$ In some specifications we cluster standard errors at the judge delivering the decision. Our results are also robust when we include the judge delivering the opinion. Regression results are available upon request.

${ }^{52}$ In the analysis presented here we are not considering judges fixed effects because some judges participated in one decision only, which would perfectly predict the outcome and some observations would be dropped. We run the regression analysis including judges fixed effects and the results are robust. The results are available upon request. 
of separate opinions in the decision as dependent variable 53 ,

$$
\text { PropSeparate }_{i}=\text { PANEL }_{i}+\text { CASE }_{i}+\eta_{t}+\epsilon_{i}
$$

The unit of analysis in this case is the decision, i.e., the 341 decisions. The vector $P A N E L_{i}$ includes variables that aggregate information on the judges constituting the panel and deciding the case, such as the total of Scottish judges, the total of female judges, the total of Law Lords, and the total of judges in majority.

\section{Results}

The first regression table (Table 5) presents the results when the dependent variable is separate and the Commonwealth appeals are the baseline. In this set of regressions, columns 1 to 3 include weights for the probability of a case being sampled, while columns 4 to 6 include weights for the probability of being sampled and panel size. We clustered the standard errors by the author judge of the opinion. We can see that deciding a devolution case is associated with a higher likelihood of delivering a separate vote than Commonwealth appeals. Scottish judges are less likely to write a separate opinion, but the results are no longer statistically significant when more covariates are added. Law Lords are more likely to write separate opinions. Seniority 54 measured by years left until retirement, does not seem to matter when it comes to presenting separate opinions. Having a Scottish judge delivering the decision seems to have a negative effect, but the level of significance is not stable.

We also consider areas of the law, namely criminal law, business law, land and property. Given that all appeals brought under devolution are cases related to rights (more precisely, under the ECHR), we include a variable for cases related to rights in Commonwealth jurisdictions. The sign of the coefficient for criminal varies across regressions and it is generally not statistically significant (the same holds for business law and land and property). The coefficients for the same jurisdiction of the case, judges and author judges are not statistically significant.

\footnotetext{
${ }^{53}$ We use GLM estimator as suggested in Baum (2008).

${ }^{54}$ Although it is not possible to have standard political control variables for judges due to the appointment process, "tenure"' should be a good proxy for this. The reason is that older judges are likely to be Tory and younger judges are likely to be Labour party appointees. The results do not show that such political variable is very relevant.
} 
Taking part in a panel in which the judge is in majority does not have any effect. Moreover, having the judge being from the same jurisdiction of the case does not have any impact on separate $\sqrt[55]{5}$ These results are robust to specifications in which we cluster the standard errors by judge (Table 6) and by decision (Table 7). As for the regressions that use the proportion of separate votes as dependent variable, the results are robust and in line with the findings when using individual votes instead (Table 8 ).

There is slight evidence that judges specialized in Scottish law are less likely to write separate opinions. One possible explanation is that judges specialized in English law are less deferent to precedent. In a sense, this is related to the findings by Hanretty (2013) which suggest that British Law Lords that specialize in English law 'are less likely to act deferentially towards English law in general and precedent in particular'. In general, Scottish law is different from English law and, at the same time, devolution appeals tend to reflect concerns over Scottish law. These two factors might explain why Scottish judges are less likely to write separate opinions and English judges more likely to do so. One should also take into account that Scottish judges tend to deliver the court judgment in devolution cases and, consequently, it is their non-Scottish peers who tend to write separate opinions.

We also find that, on average, Law Lords are more likely to write separate opinions. This is an expected result if we consider that they are likely to be more predisposed and committed to expressing and developing legal argumentation. It is also possible that they face lower costs when it comes to writing a separate opinion, because they might benefit from the resources available to them in the House of Lords Appellate Committee, in terms of time and disposition. Additionally, the likelihood of writing separate opinions was higher while Lord Bingham of Cornhill was Senior Law Lord. This is in line with previous evidence that Lord Bingham was favourable to multiple judgments.

\footnotetext{
${ }^{55}$ We performed different specifications as robustness checks, clustering by judge (Table 6) and decision (Table 7 ). In the Appendix we present regression tables excluding 2010 and 2011 since devolution cases were transferred to the Supreme Court by then. As we can see, the results are essentially the same.
} 


\section{Conclusion}

We have used the decisions of the Judicial Committee of the Privy Council to study the extent to which different types of cases induce different opinion writing behavior. Our results show that devolution cases are likely to generate more legal argumentation in the form of separate opinions (mainly concurring opinions). Our interpretation is that additional separate opinions are induced by more division concerning legal doctrines. In a first approach our results suggest that the differences between devolution appeals and others are more related to the particular constitutional significance of human rights appeals in the context of Scottish criminal law. However, there are important differences in cases related to human rights in general. The main difference between cases related to human rights that are brought under devolution or Commonwealth appeals is that judges tend to present concurring opinions in devolution cases and dissenting opinions in Commonwealth cases. We interpret these results in the following way: human rights cases are relevant enough for judges to express their opinion; in Commonwealth cases, judges feel distant from the originating jurisdiction of the case, and therefore might dissent; in devolution cases, there is a close proximity with the origin of the case and judges do not want to send a signal of dissent to the general public, and so they opt for presenting separate opinions instead.

These results can be understood in line with previous empirical work about the Law Lords (see, for example, Hanretty (2013)). Separate opinions reflect asymmetric needs with respect to doctrinal developments rather than dispositional preferences.

Two important implications for the comparative study of judicial behavior emerge from our results. They are significant within the current debates in comparative judicial politics. First, unlike suggested by traditional legal scholars, underlying schisms among judges can be a reality even in courts perceived as fairly isolated from politicization. In fact, division can also emerge among judges that have similar background characteristics. Second, division and polarization is not always firstly partisan or due to alignment of diverse party interests. It can be induced by other relevant dimensions, political or ideological in nature, but quite distinct from mere party politics. This particular kind of disagreement can be found in many common law courts. The experience of the Judicial Committee Privy Council shows that even when partisan interests 
become relevant, their effect can be dominated by nonpartisan yet still political dimensions of disagreement. As the devolution era in the Privy Council's jurisprudence demonstrates, at least some of the determinants of judicial behavior can be unique to a particular institutional and political setting. Consequently, the study of judicial behavior must always be sensitive to context. 


\section{Tables}

Table 1: Total cases by type

\begin{tabular}{lcccc}
\hline & Devolution & Domestic & Commonwealth & Total \\
\hline Unanimous decisions & 3 & 95 & 159 & 257 \\
Decisions with at least one separate & 20 & 1 & 63 & 84 \\
Decisions with at least one dissent & 1 & 1 & 48 & 50 \\
Total decisions & 23 & 96 & 222 & 341 \\
\hline
\end{tabular}

Table 2: Judges Votes according to the judges' original jurisdiction

\begin{tabular}{lcccc}
\hline Judge jurisdiction & Devolution & Domestic & Commonwealth & Total \\
\hline & \multicolumn{4}{c}{ All individual votes } \\
British-Non-Scot & 62 & 223 & 881 & 1,166 \\
Commonwealth & 0 & 15 & 42 & 57 \\
Scottish & 47 & 56 & 191 & 294 \\
Total & $\mathbf{1 0 9}$ & $\mathbf{2 9 4}$ & $\mathbf{1 , 1 1 4}$ & $\mathbf{1 , 5 1 7}$ \\
\hline & All individual votes (excluding author judge) \\
British-Non-Scot & 57 & 151 & 693 & 901 \\
Commonwealth & 0 & 10 & 33 & 43 \\
Scottish & 29 & 37 & 162 & 228 \\
Total & $\mathbf{8 6}$ & $\mathbf{1 9 8}$ & $\mathbf{8 8 8}$ & $\mathbf{1 , 1 7 2}$ \\
\hline & \multicolumn{5}{c}{ Individual votes with separate } \\
British-Non-Scot & 53 & 1 & 105 & 159 \\
Commonwealth & 0 & 0 & 2 & 2 \\
Scottish & 25 & 0 & 17 & 42 \\
Total & $\mathbf{7 8}$ & $\mathbf{1}$ & $\mathbf{1 2 4}$ & $\mathbf{2 0 3}$ \\
\hline & \multicolumn{5}{c}{ Individual votes with dissent } \\
British-Non-Scot & 2 & 1 & 75 & 78 \\
Commonwealth & 0 & 0 & 2 & 2 \\
Scottish & 0 & 0 & 10 & 10 \\
Total & $\mathbf{2}$ & $\mathbf{1}$ & $\mathbf{8 7}$ & $\mathbf{9 0}$ \\
\hline
\end{tabular}


Table 3: Variables Description

\begin{tabular}{ll}
\hline Variable Name & Definition \\
\hline Appellant individual & Appellant is an individual party \\
Appellant public & Appellant is a public party \\
Business law & Business law case \\
Commonwealth & Commonwealth appeal \\
Concurring & Judge presented a concurring opinion \\
Criminal & Criminal case \\
Scottish author & Judge delivering the decision practiced in \\
& Scottish jurisdiction \\
Devolution & Devolution appeal \\
Dissenting & Judge presented a dissenting opinion \\
Domestic & Domestic appeal (Disciplinary Committee \\
& of the Royal College of Veterinary Surgeons, \\
& General Medical Council, General Dental Council, \\
ecclesiastical courts and other ancient courts) \\
Female judge & Judge is female \\
Law Lord judge & Judge is/was a Law Lord \\
Respondent individual & Respondent is an individual party \\
Respondent public & Respondent is a public party \\
Rights-Commonwealth & Rights case from Commonwealth jurisdiction \\
& (human rights, constitutional rights or right \\
Scottish judge & to a fair trial) \\
Separate & Judge practiced in Scottish jurisdiction \\
Sen. LL Bingham & Judge presented a separate opinion (concurring \\
Total Concurring & or dissenting) \\
Total Dissenting & Decision taken when Bingham was senior Law Lord \\
Potal votes per judge & Total number of concurring votes in each decision \\
Years to retirement & Total number of dissenting votes in each decision \\
Tudge in majority & Total number of votes by each judge \\
Same jurisd. judge/author judge & Judge and author judge are from the same jurisdiction \\
& Judge and case origin are from the same jurisdiction \\
\hline & Number of years to reach 75 years old (retirement age) \\
& Judge is in majority (if the judge is Scottish and more than \\
half of the panel is Scottish; judge is English and more than \\
half of the panel is English) \\
Author judge and case origin are from the same jurisdiction \\
\end{tabular}


Table 4: Summary Statistics

\begin{tabular}{lccccc}
\hline Variable & Mean & StandardDev & Min. & Max. & $\mathrm{N}$ \\
\hline Appellant individual & 0.79 & 0.40 & 0 & 1 & 341 \\
Appellant public & 0.08 & 0.27 & 0 & 1 & 341 \\
Business law & 0.08 & 0.27 & 0 & 1 & 341 \\
Commonwealth & 0.65 & 0.48 & 0 & 1 & 341 \\
Concurring & 0.07 & 0.20 & 0 & 0.80 & 341 \\
Criminal & 0.14 & 0.35 & 0 & 1 & 341 \\
Devolution & 0.07 & 0.25 & 0 & 1 & 341 \\
Dissenting & 0.05 & 0.13 & 0 & 0.44 & 341 \\
Domestic & 0.28 & 0.45 & 0 & 1 & 341 \\
Law Lord judge & 0.83 & 0.21 & 0.20 & 1 & 341 \\
Panel size & 4.45 & 1.05 & 3 & 9 & 341 \\
Pro-appellant & 0.44 & 0.50 & 0 & 1 & 341 \\
Proportion separate & 0.14 & 0.29 & 0 & 1 & 341 \\
Respondent individual & 0.14 & 0.35 & 0 & 1 & 341 \\
Respondent public & 0.74 & 0.44 & 0 & 1 & 341 \\
Rights-Commonwealth & 0.15 & 0.36 & 0 & 1 & 341 \\
Scottish judge & 0.20 & 0.17 & 0 & 0.8 & 341 \\
Scottish author & 0.19 & 0.40 & 0 & 1 & 341 \\
Separate & 0.12 & 0.23 & 0 & 0.8 & 341 \\
Total concurring & 0.33 & 1.02 & 0 & 4 & 341 \\
Total dissenting & 0.26 & 0.69 & 0 & 4 & 341 \\
Total separate & 0.60 & 1.19 & 0 & 4 & 341 \\
Year & 2002.6 & 2.86 & 1998 & 2011 & 341 \\
Years to retirement & 6.83 & 1.81 & 2.67 & 13.33 & 341 \\
Judge is in majority & 0.65 & 0.28 & 0 & 1 & 341 \\
Same jurisd. judge/case & 0.32 & 0.42 & 0 & 1 & 341 \\
Same jurisd. judge/author judge & 0.6 & 0.26 & 0.2 & 1 & 341 \\
Same jurisd. author judge/case & 0.35 & 0.48 & 0 & 1 & 341 \\
\hline The & $0.34 t$ & 0.345
\end{tabular}

The unit of observation is: decision, if $\mathrm{N}$ is 341 ; individual vote, if $\mathrm{N}$ is 1,517; judge, if $\mathrm{N}$ is 68. 
Table 4: Summary Statistics (cont.)

\begin{tabular}{|c|c|c|c|c|c|}
\hline Variable & Mean & StandardDev & Min. & Max. & $\mathrm{N}$ \\
\hline Appellant individual & 0.77 & 0.42 & 0 & 1 & 1,517 \\
\hline Appellant public & 0.09 & 0.28 & 0 & 1 & 1,517 \\
\hline Commonwealth & 0.73 & 0.44 & 0 & 1 & 1,517 \\
\hline Concurring & 0.07 & 0.26 & 0 & 1 & 1,517 \\
\hline Devolution & 0.07 & 0.26 & 0 & 1 & 1,517 \\
\hline Dissenting & 0.06 & 0.24 & 0 & 1 & 1,517 \\
\hline Domestic & 0.19 & 0.40 & 0 & 1 & 1,517 \\
\hline Law Lord judge & 0.85 & 0.36 & 0 & 1 & 1,517 \\
\hline Pro-appellant & 0.46 & 0.50 & 0 & 1 & 1,517 \\
\hline Respondent individual & 0.17 & 0.37 & 0 & 1 & 1,517 \\
\hline Respondent public & 0.71 & 0.46 & 0 & 1 & 1,517 \\
\hline Scottish judge & 0.19 & 0.40 & 0 & 1 & 1,517 \\
\hline Separate & 0.13 & 0.34 & 0 & 1 & 1,517 \\
\hline Total concurring & 0.38 & 1.09 & 0 & 4 & 1,517 \\
\hline Total dissenting & 0.33 & 0.79 & 0 & 4 & 1,517 \\
\hline Total separate & 0.71 & 1.28 & 0 & 4 & 1,517 \\
\hline Years to retirement & 6.78 & 4.08 & 0 & 23 & 1,517 \\
\hline Judge is in majority & 0.65 & 0.48 & 0 & 1 & 1,517 \\
\hline Same jurisd. judge/case & 0.24 & 0.43 & 0 & 1 & 1,517 \\
\hline Same jurisd. judge/author judge & 0.6 & 0.49 & 0 & 1 & 1,517 \\
\hline Same jurisd. author judge/case & 0.27 & 0.44 & 0 & 1 & 1,517 \\
\hline Female judge & 0.04 & 0.21 & 0 & 1 & 68 \\
\hline Law Lord judge & 0.50 & 0.50 & 0 & 1 & 68 \\
\hline Scottish judge & 0.12 & 0.32 & 0 & 1 & 68 \\
\hline Scottish author & 0.15 & 0.19 & 0 & 1 & 68 \\
\hline Years to retirement & 6.67 & 4.75 & 0 & 21.5 & 68 \\
\hline Total votes per judge & 22.31 & 31.26 & 1 & 123 & 68 \\
\hline Total separate votes per judge & 2.99 & 4.73 & 0 & 17 & 68 \\
\hline Judge is in majority & 0.69 & 0.42 & 0 & 1 & 68 \\
\hline Same jurisd. judge/case & 0.27 & 0.32 & 0 & 1 & 68 \\
\hline Same jurisd. judge/author judge & 0.66 & 0.32 & 0 & 1 & 68 \\
\hline Same jurisd. author judge/case & 0.23 & 0.24 & 0 & 1 & 68 \\
\hline
\end{tabular}

The unit of observation is: decision, if $\mathrm{N}$ is 341 ; individual vote, if $\mathrm{N}$ is 1,517 ; judge, if $\mathrm{N}$ is 68. 
Table 5: Results for separate votes - std. errors clustered by author judge

\begin{tabular}{|c|c|c|c|c|c|c|}
\hline & Reg 1 & Reg 2 & Reg 3 & Reg 4 & Reg 5 & Reg 6 \\
\hline Devolution & $\begin{array}{c}5.84 * * * \\
(0.00)\end{array}$ & $\begin{array}{c}6.58 * * * \\
(0.00)\end{array}$ & $\begin{array}{c}6.73 * * * \\
(0.00)\end{array}$ & $\begin{array}{c}6.33 * * * \\
(0.00)\end{array}$ & $\begin{array}{c}6.95^{* * *} \\
(0.00)\end{array}$ & $\begin{array}{l}7.11^{* * * *} \\
(0.00)\end{array}$ \\
\hline Domestic & $\begin{array}{l}-2.41 * \\
(0.09)\end{array}$ & $\begin{array}{l}-0.90 \\
(0.65)\end{array}$ & $\begin{array}{l}-0.96 \\
(0.64)\end{array}$ & $\begin{array}{l}-2.73^{*} \\
(0.07)\end{array}$ & $\begin{array}{l}-1.44 \\
(0.47)\end{array}$ & $\begin{array}{l}-1.54 \\
(0.45)\end{array}$ \\
\hline Scottish judge & $\begin{array}{c}-0.62^{* *} \\
(0.04)\end{array}$ & $\begin{array}{l}-0.58 \\
(0.17)\end{array}$ & $\begin{array}{l}-0.58 \\
(0.17)\end{array}$ & $\begin{array}{c}-0.80 * * \\
(0.03)\end{array}$ & $\begin{array}{l}-0.73 \\
(0.13)\end{array}$ & $\begin{array}{l}-0.73 \\
(0.13)\end{array}$ \\
\hline Female judge & $\begin{array}{l}-0.27 \\
(0.49)\end{array}$ & $\begin{array}{c}0.01 \\
(0.98)\end{array}$ & $\begin{array}{l}-0.00 \\
(0.99)\end{array}$ & $\begin{array}{l}-0.46 \\
(0.28)\end{array}$ & $\begin{array}{l}-0.08 \\
(0.84)\end{array}$ & $\begin{array}{l}-0.10 \\
(0.81)\end{array}$ \\
\hline Law Lord judge & $\begin{array}{l}1.00 * * \\
(0.03)\end{array}$ & $\begin{array}{l}1.03 * * \\
(0.04)\end{array}$ & $\begin{array}{l}1.05^{* *} \\
(0.03)\end{array}$ & $\begin{array}{l}1.10 * * \\
(0.03)\end{array}$ & $\begin{array}{l}1.11 * * \\
(0.04)\end{array}$ & $\begin{array}{l}1.14 * * \\
(0.03)\end{array}$ \\
\hline Seniority & $\begin{array}{l}-0.00 \\
(0.94)\end{array}$ & $\begin{array}{l}-0.00 \\
(0.99)\end{array}$ & $\begin{array}{l}-0.00 \\
(0.96)\end{array}$ & $\begin{array}{c}0.00 \\
(0.94)\end{array}$ & $\begin{array}{c}0.00 \\
(0.84)\end{array}$ & $\begin{array}{c}0.00 \\
(0.87)\end{array}$ \\
\hline Scottish author & $\begin{array}{c}0.28 \\
(0.41)\end{array}$ & $\begin{array}{c}0.24 \\
(0.49)\end{array}$ & $\begin{array}{c}0.20 \\
(0.58)\end{array}$ & $\begin{array}{c}0.40 \\
(0.26)\end{array}$ & $\begin{array}{c}0.25 \\
(0.46)\end{array}$ & $\begin{array}{c}0.21 \\
(0.55)\end{array}$ \\
\hline Sen. LL Bingham & $\begin{array}{c}3.12 * * * \\
(0.00)\end{array}$ & $\begin{array}{c}3.03 * * * \\
(0.00)\end{array}$ & $\begin{array}{c}3.13 * * * \\
(0.00)\end{array}$ & $\begin{array}{c}3.34 * * * \\
(0.00)\end{array}$ & $\begin{array}{c}3.16 * * * \\
(0.00)\end{array}$ & $\begin{array}{c}3.28 * * * \\
(0.00)\end{array}$ \\
\hline Business law & $\begin{array}{l}-0.45 \\
(0.60)\end{array}$ & $\begin{array}{l}-0.37 \\
(0.67)\end{array}$ & $\begin{array}{l}-0.54 \\
(0.52)\end{array}$ & $\begin{array}{l}-0.47 \\
(0.60)\end{array}$ & $\begin{array}{l}-0.37 \\
(0.67)\end{array}$ & $\begin{array}{l}-0.54 \\
(0.52)\end{array}$ \\
\hline Criminal & $\begin{array}{c}0.14 \\
(0.77)\end{array}$ & $\begin{array}{l}-0.02 \\
(0.96)\end{array}$ & $\begin{array}{l}-0.18 \\
(0.72)\end{array}$ & $\begin{array}{c}0.28 \\
(0.56)\end{array}$ & $\begin{array}{c}0.02 \\
(0.98)\end{array}$ & $\begin{array}{l}-0.14 \\
(0.77)\end{array}$ \\
\hline Rights-Commonw. & $\begin{array}{l}0.80 * * \\
(0.03)\end{array}$ & $\begin{array}{c}0.40 \\
(0.27)\end{array}$ & $\begin{array}{c}0.33 \\
(0.38)\end{array}$ & $\begin{array}{l}0.98 * * \\
(0.01)\end{array}$ & $\begin{array}{c}0.44 \\
(0.23)\end{array}$ & $\begin{array}{c}0.36 \\
(0.35)\end{array}$ \\
\hline Land and property & $\begin{array}{l}-0.83 \\
(0.18)\end{array}$ & $\begin{array}{l}-0.80 \\
(0.17)\end{array}$ & $\begin{array}{l}-0.92 \\
(0.15)\end{array}$ & $\begin{array}{c}-0.90 \\
(0.17)\end{array}$ & $\begin{array}{l}-0.84 \\
(0.16)\end{array}$ & $\begin{array}{l}-0.96 \\
(0.14)\end{array}$ \\
\hline Panel size & & $\begin{array}{c}0.76 * * * * \\
(0.00)\end{array}$ & $\begin{array}{c}0.77 * * * \\
(0.00)\end{array}$ & & $\begin{array}{c}0.70 * * * * \\
(0.00)\end{array}$ & $\begin{array}{c}0.72^{* * *} \\
(0.00)\end{array}$ \\
\hline Pro-appellant & & $\begin{array}{l}-0.30 \\
(0.47)\end{array}$ & $\begin{array}{l}-0.33 \\
(0.44)\end{array}$ & & $\begin{array}{l}-0.31 \\
(0.45)\end{array}$ & $\begin{array}{l}-0.34 \\
(0.41)\end{array}$ \\
\hline Judge is in majority & & $\begin{array}{l}-0.00 \\
(0.99)\end{array}$ & $\begin{array}{l}-0.01 \\
(0.98)\end{array}$ & & $\begin{array}{c}0.06 \\
(0.88)\end{array}$ & $\begin{array}{c}0.05 \\
(0.89)\end{array}$ \\
\hline Same jurisd. judge/case & & $\begin{array}{l}-0.33 \\
(0.35)\end{array}$ & $\begin{array}{l}-0.33 \\
(0.35)\end{array}$ & & $\begin{array}{l}-0.52 \\
(0.18)\end{array}$ & $\begin{array}{l}-0.52 \\
(0.18)\end{array}$ \\
\hline Same jurisd. judge/author judge & & $\begin{array}{c}0.07 \\
(0.81)\end{array}$ & $\begin{array}{c}0.06 \\
(0.83)\end{array}$ & & $\begin{array}{c}0.05 \\
(0.86)\end{array}$ & $\begin{array}{c}0.04 \\
(0.89)\end{array}$ \\
\hline Same jurisd. author judge/case & & $\begin{array}{l}-0.73 \\
(0.45)\end{array}$ & $\begin{array}{l}-0.89 \\
(0.39)\end{array}$ & & $\begin{array}{l}-0.59 \\
(0.52)\end{array}$ & $\begin{array}{l}-0.76 \\
(0.45)\end{array}$ \\
\hline Appellant individual & & & $\begin{array}{l}-0.13 \\
(0.70)\end{array}$ & & & $\begin{array}{l}-0.13 \\
(0.69)\end{array}$ \\
\hline Respondent individual & & & $\begin{array}{l}-0.52 \\
(0.32)\end{array}$ & & & $\begin{array}{l}-0.56 \\
(0.29)\end{array}$ \\
\hline Constant & $\begin{array}{c}-3.74 * * * \\
(0.00)\end{array}$ & $\begin{array}{c}-7.29 * * * * \\
(0.00)\end{array}$ & $\begin{array}{c}-7.08 * * * * \\
(0.00)\end{array}$ & $\begin{array}{c}-3.99 * * * \% \\
(0.00)\end{array}$ & $\begin{array}{c}-7.18 * * * * \\
(0.00)\end{array}$ & $\begin{array}{c}-6.99 * \cdots * * \\
(0.00)\end{array}$ \\
\hline Observations & 1,168 & 1,168 & 1,168 & 1,168 & 1,168 & 1,168 \\
\hline
\end{tabular}

Note: Robust $\mathrm{p}$-values by author judge in parentheses. ${ }^{*} \mathrm{p}<0.1,{ }^{* *} \mathrm{p}<0.05,{ }^{* * *} \mathrm{p}<0.01$. All regressions include year fixed effects. Regs. 1, 2 and 3 with weights for the probability of being sampled. Regs. 4, 5 and 6 with weights for the probability of being sampled and panel size. 
Table 6: Results for separate votes - std. errors clustered by judge

\begin{tabular}{|c|c|c|c|c|c|c|}
\hline & Reg 1 & Reg 2 & Reg 3 & Reg 4 & Reg 5 & Reg 6 \\
\hline \multirow[t]{2}{*}{ Devolution } & $5.84 * * *$ & $6.58 * * *$ & $6.73 * * *$ & $6.33 * * *$ & $6.95 * * *$ & $7.11^{* * *}$ \\
\hline & $(0.00)$ & $(0.00)$ & $(0.00)$ & $(0.00)$ & $(0.00)$ & $(0.00)$ \\
\hline \multirow[t]{2}{*}{ Domestic } & $-2.41 *$ & -0.90 & -0.96 & $-2.73 *$ & -1.44 & -1.54 \\
\hline & $(0.05)$ & $(0.55)$ & $(0.53)$ & $(0.07)$ & $(0.47)$ & $(0.45)$ \\
\hline \multirow{2}{*}{ Scottish judge } & $-0.62 * * *$ & $-0.58 * * *$ & $-0.58 * * *$ & $-0.80 * *$ & -0.73 & -0.73 \\
\hline & $(0.00)$ & $(0.00)$ & $(0.00)$ & $(0.03)$ & $(0.13)$ & $(0.13)$ \\
\hline \multirow[t]{2}{*}{ Female judge } & -0.27 & 0.01 & -0.00 & -0.46 & -0.08 & -0.10 \\
\hline & $(0.20)$ & $(0.96)$ & $(0.98)$ & $(0.28)$ & $(0.84)$ & $(0.81)$ \\
\hline \multirow[t]{2}{*}{ Law Lord judge } & $1.00 * * *$ & $1.03 * * *$ & $1.05 * * *$ & $1.10 * *$ & $1.11^{* *}$ & $1.14^{* *}$ \\
\hline & $(0.00)$ & $(0.01)$ & $(0.00)$ & $(0.03)$ & $(0.04)$ & $(0.03)$ \\
\hline \multirow[t]{2}{*}{ Seniority } & -0.00 & -0.00 & -0.00 & 0.00 & 0.00 & 0.00 \\
\hline & $(0.94)$ & (0.99) & $(0.96)$ & $(0.94)$ & $(0.84)$ & $(0.87)$ \\
\hline \multirow[t]{2}{*}{ Scottish author } & 0.28 & 0.24 & 0.20 & 0.40 & 0.25 & 0.21 \\
\hline & $(0.37)$ & $(0.52)$ & $(0.58)$ & $(0.26)$ & $(0.46)$ & $(0.55)$ \\
\hline \multirow[t]{2}{*}{ Sen. LL Bingham } & $3.12 * * *$ & $3.03 * * *$ & $3.13 * * *$ & $3.34 * * *$ & $3.16 * * *$ & $3.28 * * *$ \\
\hline & $(0.00)$ & $(0.00)$ & $(0.00)$ & $(0.00)$ & $(0.00)$ & $(0.00)$ \\
\hline \multirow[t]{2}{*}{ Business law } & -0.45 & -0.37 & -0.54 & -0.47 & -0.37 & -0.54 \\
\hline & $(0.29)$ & $(0.35)$ & $(0.17)$ & $(0.60)$ & $(0.67)$ & $(0.52)$ \\
\hline \multirow[t]{2}{*}{ Criminal } & 0.14 & -0.02 & -0.18 & 0.28 & 0.02 & -0.14 \\
\hline & $(0.76)$ & $(0.96)$ & $(0.74)$ & $(0.56)$ & $(0.98)$ & $(0.77)$ \\
\hline \multirow[t]{2}{*}{ Rights-Commonw. } & $0.80 * *$ & 0.40 & 0.33 & $0.98 * *$ & 0.44 & 0.36 \\
\hline & $(0.03)$ & $(0.23)$ & $(0.33)$ & $(0.01)$ & $(0.23)$ & $(0.35)$ \\
\hline \multirow[t]{2}{*}{ Land and property } & $-0.83 * *$ & $-0.80 *$ & $-0.92 * *$ & -0.90 & -0.84 & -0.96 \\
\hline & $(0.04)$ & $(0.05)$ & $(0.04)$ & $(0.17)$ & $(0.16)$ & $(0.14)$ \\
\hline \multirow[t]{2}{*}{ Panel size } & & $0.76 * * *$ & $0.77 * * *$ & & $0.70 * * *$ & $0.72 * * *$ \\
\hline & & $(0.00)$ & $(0.00)$ & & $(0.00)$ & $(0.00)$ \\
\hline \multirow[t]{2}{*}{ Pro-appellant } & & -0.30 & -0.33 & & -0.31 & -0.34 \\
\hline & & $(0.27)$ & $(0.23)$ & & $(0.45)$ & $(0.41)$ \\
\hline \multirow[t]{2}{*}{ Judge is in majority } & & -0.00 & -0.01 & & 0.06 & 0.05 \\
\hline & & $(0.99)$ & $(0.98)$ & & $(0.88)$ & $(0.89)$ \\
\hline \multirow[t]{2}{*}{ Same jurisd. judge/case } & & -0.33 & -0.33 & & -0.52 & -0.52 \\
\hline & & $(0.52)$ & $(0.52)$ & & $(0.18)$ & $(0.18)$ \\
\hline \multirow[t]{2}{*}{ Same jurisd. author judge/case } & & -0.73 & -0.89 & & -0.59 & -0.76 \\
\hline & & $(0.15)$ & $(0.13)$ & & $(0.52)$ & $(0.45)$ \\
\hline \multirow[t]{2}{*}{ Same jurisd. judge/author judge } & & 0.07 & 0.06 & & 0.05 & 0.04 \\
\hline & & $(0.79)$ & $(0.81)$ & & $(0.86)$ & $(0.89)$ \\
\hline \multirow[t]{2}{*}{ Appellant individual } & & & -0.13 & & & -0.13 \\
\hline & & & $(0.61)$ & & & $(0.69)$ \\
\hline \multirow[t]{2}{*}{ Respondent individual } & & & -0.52 & & & -0.56 \\
\hline & & & $(0.16)$ & & & $(0.29)$ \\
\hline \multirow[t]{2}{*}{ Constant } & $-3.74 * * *$ & $-7.29 * * *$ & $-7.08 * * *$ & $-3.99 * * *$ & $-7.18 * * *$ & $-6.99 * * *$ \\
\hline & $(0.00)$ & $(0.00)$ & $(0.00)$ & $(0.00)$ & $(0.00)$ & $(0.00)$ \\
\hline Observations & 1,168 & 1,168 & 1,168 & 1,168 & 1,168 & 1,168 \\
\hline
\end{tabular}

Note: Robust $\mathrm{p}$-values by judge in parentheses. ${ }^{*} \mathrm{p}<0.1,{ }^{* *} \mathrm{p}<0.05$, $* * * \mathrm{p}<0.01$. All regressions include year fixed effects. Regs. 1, 2 and 3 with weights for the probability of being sampled. Regs. 4, 5 and 6 with weights for the probability of being sampled and panel size. 
Table 7: Results for separate votes - std. errors clustered by decision

\begin{tabular}{|c|c|c|c|c|c|c|}
\hline & Reg 1 & Reg 2 & Reg 3 & Reg 4 & Reg 5 & Reg 6 \\
\hline \multirow[t]{2}{*}{ Devolution } & $5.84 \% * *$ & $6.58 * * *$ & $6.73 * * *$ & $6.33 \% * *$ & $6.95 \% * *$ & $7.11 \% * *$ \\
\hline & $(0.00)$ & $(0.00)$ & $(0.00)$ & $(0.00)$ & $(0.00)$ & $(0.00)$ \\
\hline \multirow[t]{2}{*}{ Domestic } & $-2.41 *$ & -0.90 & -0.96 & $-2.73 * *$ & -1.44 & -1.54 \\
\hline & $(0.07)$ & $(0.66)$ & $(0.64)$ & $(0.05)$ & $(0.48)$ & $(0.46)$ \\
\hline \multirow{2}{*}{ Scottish judge } & $-0.62 * *$ & $-0.58 *$ & $-0.58 *$ & $-0.80 * *$ & $-0.73 *$ & $-0.73 *$ \\
\hline & $(0.02)$ & $(0.09)$ & (0.09) & $(0.01)$ & $(0.05)$ & $(0.05)$ \\
\hline \multirow[t]{2}{*}{ Female judge } & -0.27 & 0.01 & -0.00 & -0.46 & -0.08 & -0.10 \\
\hline & $(0.51)$ & $(0.98)$ & $(0.99)$ & $(0.29)$ & $(0.85)$ & $(0.82)$ \\
\hline \multirow[t]{2}{*}{ Law Lord judge } & $1.00 * * *$ & $1.03 * *$ & $1.05 * * *$ & $1.10 * * *$ & $1.11^{* *}$ & $1.14 * * *$ \\
\hline & $(0.01)$ & $(0.01)$ & $(0.01)$ & $(0.00)$ & $(0.01)$ & $(0.01)$ \\
\hline \multirow[t]{2}{*}{ Seniority } & -0.00 & -0.00 & -0.00 & 0.00 & 0.00 & 0.00 \\
\hline & $(0.94)$ & (0.99) & $(0.96)$ & $(0.94)$ & $(0.84)$ & $(0.87)$ \\
\hline \multirow[t]{2}{*}{ Scottish author } & 0.28 & 0.24 & 0.20 & 0.40 & 0.25 & 0.21 \\
\hline & $(0.54)$ & $(0.63)$ & $(0.70)$ & $(0.35)$ & $(0.59)$ & $(0.66)$ \\
\hline \multirow[t]{2}{*}{ Sen. LL Bingham } & $3.12 * * *$ & $3.03 * * *$ & $3.13 * * *$ & $3.34 * * *$ & $3.16 * * *$ & $3.28 * * *$ \\
\hline & $(0.00)$ & $(0.00)$ & $(0.00)$ & $(0.00)$ & $(0.00)$ & $(0.00)$ \\
\hline \multirow[t]{2}{*}{ Business law } & -0.45 & -0.37 & -0.54 & -0.47 & -0.37 & -0.54 \\
\hline & $(0.51)$ & $(0.58)$ & $(0.43)$ & $(0.50)$ & $(0.57)$ & $(0.43)$ \\
\hline \multirow[t]{2}{*}{ Criminal } & 0.14 & -0.02 & -0.18 & 0.28 & 0.02 & -0.14 \\
\hline & $(0.79)$ & $(0.97)$ & $(0.76)$ & $(0.59)$ & $(0.98)$ & $(0.81)$ \\
\hline \multirow[t]{2}{*}{ Rights-Commonw. } & $0.80 *$ & 0.40 & 0.33 & $0.98 * *$ & 0.44 & 0.36 \\
\hline & $(0.06)$ & $(0.36)$ & $(0.47)$ & $(0.02)$ & $(0.32)$ & $(0.43)$ \\
\hline \multirow[t]{2}{*}{ Land and property } & -0.83 & -0.80 & -0.92 & -0.90 & -0.84 & -0.96 \\
\hline & $(0.21)$ & $(0.21)$ & $(0.19)$ & $(0.18)$ & $(0.19)$ & $(0.18)$ \\
\hline \multirow[t]{2}{*}{ Panel size } & & $0.76 * * *$ & $0.77 * * *$ & & $0.70 * * *$ & $0.72 * * *$ \\
\hline & & $(0.00)$ & $(0.00)$ & & $(0.00)$ & $(0.00)$ \\
\hline \multirow[t]{2}{*}{ Pro-appellant } & & -0.30 & -0.33 & & -0.31 & -0.34 \\
\hline & & $(0.42)$ & $(0.38)$ & & $(0.39)$ & $(0.35)$ \\
\hline \multirow[t]{2}{*}{ Judge is in majority } & & -0.00 & -0.01 & & 0.06 & 0.05 \\
\hline & & $(0.99)$ & $(0.98)$ & & $(0.88)$ & $(0.89)$ \\
\hline \multirow[t]{2}{*}{ Same jurisd. judge/case } & & -0.33 & -0.33 & & -0.52 & -0.52 \\
\hline & & $(0.54)$ & $(0.54)$ & & $(0.38)$ & $(0.38)$ \\
\hline \multirow[t]{2}{*}{ Same jurisd. author judge/case } & & -0.73 & -0.89 & & -0.59 & -0.76 \\
\hline & & $(0.50)$ & $(0.43)$ & & $(0.58)$ & $(0.50)$ \\
\hline \multirow{2}{*}{ Same jurisd. judge/author judge } & & 0.07 & 0.06 & & 0.05 & 0.04 \\
\hline & & $(0.82)$ & $(0.84)$ & & $(0.87)$ & $(0.89)$ \\
\hline \multirow[t]{2}{*}{ Appellant individual } & & & -0.13 & & & -0.13 \\
\hline & & & $(0.74)$ & & & $(0.74)$ \\
\hline \multirow[t]{2}{*}{ Respondent individual } & & & -0.52 & & & -0.56 \\
\hline & & & $(0.32)$ & & & $(0.29)$ \\
\hline \multirow[t]{2}{*}{ Constant } & $-3.74 * * *$ & $-7.29 * * *$ & $-7.08 * * *$ & $-3.99 * * *$ & $-7.18 * * *$ & $-6.99 * * *$ \\
\hline & $(0.00)$ & $(0.00)$ & $(0.00)$ & $(0.00)$ & $(0.00)$ & $(0.00)$ \\
\hline Observations & 1,168 & 1,168 & 1,168 & 1,168 & 1,168 & 1,168 \\
\hline
\end{tabular}

Note: Robust $\mathrm{p}$-values by decision in parentheses. ${ }^{*} \mathrm{p}<0.1, * * \mathrm{p}<0.05, * * * \mathrm{p}<0.01$. All regressions include year fixed effects. Regs. 1, 2 and 3 with weights for the probability of being sampled. Regs. 4, 5 and 6 with weights for the probability of being sampled and panel size. 
Table 8: Results for proportion of separate votes

\begin{tabular}{|c|c|c|c|c|c|c|}
\hline & Reg 1 & Reg 2 & Reg 3 & Reg 4 & Reg 5 & Reg 6 \\
\hline Devolution & $\begin{array}{c}4.24 * * * \\
(0.00)\end{array}$ & $\begin{array}{c}3.86 * * * \\
(0.01)\end{array}$ & $\begin{array}{c}4.08 * * * \\
(0.00)\end{array}$ & $\begin{array}{c}4.24 * * * \\
(0.00)\end{array}$ & $\begin{array}{c}3.86^{* * * *} \\
(0.01)\end{array}$ & $\begin{array}{c}3.86^{* * * *} \\
(0.01)\end{array}$ \\
\hline Domestic & $\begin{array}{c}-2.47^{* * *} \\
(0.04)\end{array}$ & $\begin{array}{l}-3.04 \\
(0.24)\end{array}$ & $\begin{array}{l}-3.19 \\
(0.18)\end{array}$ & $\begin{array}{c}-2.47^{* * *} \\
(0.05)\end{array}$ & $\begin{array}{l}-3.04 \\
(0.28)\end{array}$ & $\begin{array}{l}-3.02 \\
(0.29)\end{array}$ \\
\hline Total Scottish & $\begin{array}{l}-0.22 \\
(0.36)\end{array}$ & $\begin{array}{l}-0.35 \\
(0.19)\end{array}$ & $\begin{array}{l}-0.36 \\
(0.18)\end{array}$ & $\begin{array}{l}-0.22 \\
(0.26)\end{array}$ & $\begin{array}{l}-0.35 \\
(0.18)\end{array}$ & $\begin{array}{l}-0.35 \\
(0.19)\end{array}$ \\
\hline Total female & $\begin{array}{l}-0.14 \\
(0.69)\end{array}$ & $\begin{array}{l}-0.28 \\
(0.45)\end{array}$ & $\begin{array}{l}-0.15 \\
(0.67)\end{array}$ & $\begin{array}{l}-0.14 \\
(0.73)\end{array}$ & $\begin{array}{l}-0.28 \\
(0.50)\end{array}$ & $\begin{array}{l}-0.27 \\
(0.52)\end{array}$ \\
\hline Total Law Lords & $\begin{array}{c}0.52 * * * \\
(0.00)\end{array}$ & $\begin{array}{l}0.53 * * \\
(0.01)\end{array}$ & $\begin{array}{c}0.57 * * * \\
(0.01)\end{array}$ & $\begin{array}{c}0.52 * * * \\
(0.00)\end{array}$ & $\begin{array}{l}0.53^{* *} \\
(0.03)\end{array}$ & $\begin{array}{l}0.53 * * \\
(0.03)\end{array}$ \\
\hline Avg Sen. Years(Panel) & $\begin{array}{l}-0.14 \\
(0.27)\end{array}$ & $\begin{array}{l}-0.17 \\
(0.16)\end{array}$ & $\begin{array}{l}-0.16 \\
(0.20)\end{array}$ & $\begin{array}{l}-0.14 \\
(0.19)\end{array}$ & $\begin{array}{l}-0.17^{*} \\
(0.08)\end{array}$ & $\begin{array}{l}-0.17^{*} \\
(0.08)\end{array}$ \\
\hline Scottish author & $\begin{array}{c}0.04 \\
(0.92)\end{array}$ & $\begin{array}{c}0.77 \\
(0.19)\end{array}$ & $\begin{array}{c}0.24 \\
(0.59)\end{array}$ & $\begin{array}{c}0.04 \\
(0.89)\end{array}$ & $\begin{array}{c}0.77 \\
(0.12)\end{array}$ & $\begin{array}{c}0.77 \\
(0.13)\end{array}$ \\
\hline Sen. LL Bingham & $\begin{array}{c}2.18^{* * * *} \\
(0.01)\end{array}$ & $\begin{array}{c}2.32^{* * * *} \\
(0.01)\end{array}$ & $\begin{array}{c}2.39 * * * \\
(0.01)\end{array}$ & $\begin{array}{c}2.18^{* * * *} \\
(0.00)\end{array}$ & $\begin{array}{c}2.32 * * * \\
(0.00)\end{array}$ & $\begin{array}{c}2.33^{* * * *} \\
(0.00)\end{array}$ \\
\hline Business law & $\begin{array}{l}-0.29 \\
(0.60)\end{array}$ & $\begin{array}{l}-0.23 \\
(0.67)\end{array}$ & $\begin{array}{l}-0.24 \\
(0.65)\end{array}$ & $\begin{array}{l}-0.29 \\
(0.66)\end{array}$ & $\begin{array}{l}-0.23 \\
(0.73)\end{array}$ & $\begin{array}{l}-0.27 \\
(0.67)\end{array}$ \\
\hline Criminal & $\begin{array}{l}-0.10 \\
(0.82)\end{array}$ & $\begin{array}{l}-0.14 \\
(0.76)\end{array}$ & $\begin{array}{l}-0.09 \\
(0.84)\end{array}$ & $\begin{array}{l}-0.10 \\
(0.80)\end{array}$ & $\begin{array}{l}-0.14 \\
(0.73)\end{array}$ & $\begin{array}{l}-0.14 \\
(0.72)\end{array}$ \\
\hline Rights-Commonw. & $\begin{array}{c}0.38 \\
(0.28)\end{array}$ & $\begin{array}{c}0.39 \\
(0.26)\end{array}$ & $\begin{array}{c}0.38 \\
(0.31)\end{array}$ & $\begin{array}{c}0.38 \\
(0.15)\end{array}$ & $\begin{array}{c}0.39 \\
(0.14)\end{array}$ & $\begin{array}{c}0.40 \\
(0.19)\end{array}$ \\
\hline Land and property & $\begin{array}{l}-0.64 \\
(0.32)\end{array}$ & $\begin{array}{l}-0.68 \\
(0.26)\end{array}$ & $\begin{array}{l}-0.67 \\
(0.29)\end{array}$ & $\begin{array}{l}-0.64 \\
(0.22)\end{array}$ & $\begin{array}{l}-0.68 \\
(0.16)\end{array}$ & $\begin{array}{l}-0.70 \\
(0.16)\end{array}$ \\
\hline Pro-appellant & & $\begin{array}{l}-0.21 \\
(0.45)\end{array}$ & $\begin{array}{l}-0.22 \\
(0.41)\end{array}$ & & $\begin{array}{l}-0.21 \\
(0.51)\end{array}$ & $\begin{array}{l}-0.20 \\
(0.51)\end{array}$ \\
\hline Total judges in majority & & $\begin{array}{l}-0.25^{*} \\
(0.08)\end{array}$ & $\begin{array}{l}-0.10 \\
(0.40)\end{array}$ & & $\begin{array}{l}-0.25 * \\
(0.07)\end{array}$ & $\begin{array}{l}-0.25^{*} \\
(0.07)\end{array}$ \\
\hline Total same jurisd. judge/case & & $\begin{array}{c}0.43 \\
(0.28)\end{array}$ & $\begin{array}{c}0.42 \\
(0.32)\end{array}$ & & $\begin{array}{c}0.43 \\
(0.40)\end{array}$ & $\begin{array}{c}0.42 \\
(0.41)\end{array}$ \\
\hline Total same jurisd. judge/author judge & & $\begin{array}{l}0.27 * \\
(0.08)\end{array}$ & & & $\begin{array}{l}0.27 * \\
(0.06)\end{array}$ & $\begin{array}{l}0.27^{*} \\
(0.06)\end{array}$ \\
\hline Same jurisd. author judge/case & & $\begin{array}{l}-1.03 \\
(0.41)\end{array}$ & $\begin{array}{l}-0.91 \\
(0.37)\end{array}$ & & $\begin{array}{l}-1.03 \\
(0.37)\end{array}$ & $\begin{array}{l}-1.04 \\
(0.37)\end{array}$ \\
\hline Appellant individual & & & $\begin{array}{l}-0.07 \\
(0.84)\end{array}$ & & & $\begin{array}{l}-0.07 \\
(0.81)\end{array}$ \\
\hline Respondent individual & & & $\begin{array}{l}-0.09 \\
(0.82)\end{array}$ & & & $\begin{array}{l}-0.07 \\
(0.84)\end{array}$ \\
\hline Constant & $\begin{array}{c}-2.62 * * \\
(0.03)\end{array}$ & $\begin{array}{l}-2.20^{*} \\
(0.05)\end{array}$ & $\begin{array}{l}-2.07^{*} \\
(0.08)\end{array}$ & $\begin{array}{c}-2.62 * * \\
(0.05)\end{array}$ & $\begin{array}{c}-2.20 * * \\
(0.04)\end{array}$ & $\begin{array}{c}-2.15 * * \\
(0.04)\end{array}$ \\
\hline Observations & 341 & 341 & 341 & 341 & 341 & 341 \\
\hline
\end{tabular}

Note: Regs. 1-3 with robust standard errors; Regs. 4-6 with clustered standard errors by author judge. ${ }^{*} \mathrm{p}<0.1,{ }^{* *} \mathrm{p}<0.05$, $* * * \mathrm{p}<0.01$. 


\section{References}

Alarie, B., AND A. J. Green (2008): "Should They All Just Get Along? Judicial Ideology, Collegiality, and Appointments to the Supreme Court of Canada," University of New Brunswick Law Journal, 53, 73-91.

Alder, J. (2000): "Dissents in Courts of Last Resort: Tragic Choices," Oxford Journal of Legal Studies, 20 (2), 221-246.

Amaral Garcia, S., G. Nuno, and V. Grembi (2009): "Judicial Independence and Party Politics in the Kelsenian Constitutional Courts: the Case of Portugal," Journal of Empirical Legal Studies, 6, 383-404.

ARVIND, T., AND L. STIRTON (2012): "Lawyers and the Legal Model: Judicial Ideology, Judicial Professionalism and Institutional Strategy Among the Law Lords," mimeograph in file with authors.

BAUM, C. F. (2008): “Stata tip 63: Modeling proportions,” Stata Journal, 8(2), 299-303.

Beth, L. (1975): “The Judicial Committee: Its Development, Organisation and Procedure," Public Law, 3/4, 219-241.

Blanes I VidAL, J., AND C. LEAVER (2011): "Are tenured judges insulated from political pressure?," Journal of Public Economics, 95, 570-586.

(2013): "Social Interactions and the Content of Legal Opinions," Journal of Law, Economics and Organization, 29 (1), 78-114.

Brenner, S., And H. J. Spaeth (1988): "Ideological Position as a Variable in the Authoring of Dissenting Opinions on the Warren and Burger Courts," American Politics Quarterly, 16, $317-28$.

BREton, A., AND A. FRASCHINI (2003): "The Independence of the Italian Constitutional Court," Constitutional Political Economy, 14, 319-33.

Brodie, P. H. (2009): "From Scotland and Ireland," in The Judicial House of Lords: 1876-2009, ed. by L. Blom-Cooper, G. Drewry, and B. Dickson, p. 279. Oxford University Press. 
Cameron, C. M., And L. A. Kornhauser (2010): "Modeling Collegial Courts III: Adjudication Equilibria," SSRN Working-paper.

CARroll, R., And L. Tiede (2011): "Judicial Behavior on the Chilean Constitutional Court," Journal of Empirical Legal Studies, 8, 856-77.

ChÁvez, R. B. (2004): “The Rule of Law in Nascent Democracies: Judicial Politics in Argentina," Palo Alto: Stanford University Press.

Dalla Pellegrina, L., AND N. Garoupa (2013): "Choosing between the Government and the Regions: An Empirical Analysis of the Italian Constitutional Court Decisions," European Journal of Political Research, 52 (4), 431-480.

Dalla Pellegrina, L., N. Garoupa, and S. Lin (2012): “Judicial Ideal Points in New Democracies: The Case of Taiwan," National Taiwan University Law Review, 7(1), 123-165.

DAvid SWINFEn (1987): Imperial appeal: the Debate on the Appeal to the Privy Council, 18331986. Manchester.

Delaney, E. F. (2014): “Judiciary Rising- Constitutional Change in the United Kingdom," Northwestern University Law Review, 108(2), 534-605.

Edelman, P. H., D. Klein, And S. A. Lindquist (2012): “Consensus, Disorder, and Ideology on the Supreme Court," Journal of Empirical Legal Studies, 9, 129-148.

EISENBERG, T., T. FisheR, AND I. Rosen-Zvi (2011): “Israel's Supreme Court Appellate Jurisdiction: An Empirical Study," Cornell Law Review, 96(4).

(2012): "Does the Judge Matter? Exploiting Random Assignment on a Court of Last Resort to Assess Judge and Case Selection Effects," Journal of Empirical Legal Studies, 9(2), 246-290.

EISEnBerG, T., T. FisheR, AND I. Rosen-Zvi (2013): "Group Decision Making on Appellate Panels: Presiding Justice and Opinion Justice Influence in the Israel Supreme Court," Psychology, Public Policy, and Law, 19(3), 282-296. 
Epstein, L., And J. Knight (1998): The Choices Justices Make. Washington, D.C.: Congressional Quarterly Inc.

Epstein, L., W. M. LANDes, ANd R. A. Posner (2011): "Why (and when) Judges Dissent: A Theoretical and Empirical Analysis," Journal of Legal Analysis, 3 (1), 101-137.

Epstein, L., J. A. Segal, AND H. J. Spaeth (2001): “The Norm of Consensus on the U.S. Supreme Court," American Journal of Political Science, 45, 362-77.

Escresa, L., AND N. Garoupa (2012): “Judicial Politics in Unstable Democracies: The Case of the Philippine Supreme Court, 1986-2010," Asian Journal of Law and Economics, 3.

Fiorino, N., F. PADOVANO, AND G. SGARRA (2007): “The Determinants of Judicial Independence: Evidence from the Italian Constitutional Court (1956-2002)," Journal of Institutional and Theoretical Economics, 163, 683-705.

Fischman, J. B. (2013): "Interpreting Circuit Court Voting Patterns: A Social Interactions Framework," Journal of Law, Economics, and Organization, doi: 10.1093/jleo/ews042.

FrancK, R. (2009): “Judicial Independence under a Divided Polity: A Study of the Rulings of the French Constitutional Court, 1959-2006," Journal of Law, Economics and Organization, $25,262-84$.

(2010): "Judicial Independence and the Validity of Controverted Elections," American Law and Economics Review, 12, 394-422.

Garoupa, N., M. GILI, AND F. GómeZ-Pomar (2012): “Political Influence and Career Judiciary: An Empirical Analysis of Administrative Review by the Spanish Supreme Court," Journal of Empirical Legal Studies, 9 (4), 795-826.

Garoupa, N., F. Gómez-Pomar, and V. Grembi (2013): "Judging under Political Pressure: An Empirical Analysis of Constitutional Review Voting in the Spanish Constitutional Court," Journal of Law, Economics and Organization, 29 (3), 513-534.

Garoupa, N., V. Grembi, ANd S. Lin (2011): "Explaining Constitutional Review in New Democracies: The Case of Taiwan," Pacific Rim Law and Policy Journal, 20, 1-40. 
Gely, R., And P. T. SpIlleR (1990): "A Rational Choice Theory of Supreme Court Statutory Decisions with Applications to the State Farm and Grove City Cases," Journal of Law, Economics and Organization, 6, 263-300.

George, T. E., And L. Epstein (1992): "On the Nature of Supreme Court Decision Making," American Political Science Review, 86, 323-37.

Ginsburg, T. (2003): Judicial Review in New Democracies: Constitutional Courts in Asian Cases. Cambridge: Cambridge University Press.

GofF, B. (2006): "Supreme Court Consensus and Dissent: Estimating the Role of the Selection Screen," Public Choice, 127, 367-83.

Green, A. J., And B. Alarie (2009): "Policy Preference Change and Appointments to the Supreme Court of Canada," Osgoode Hall Law Journal, 47, 1-46.

Griffith, J. A. G. (1997): The Politics of the Judiciary. Fontana Press.

Hanretty, C. (2013): “The Decisions and Ideal Points of British Law Lords," British Journal of Political Science, 43 (03), 703-716.

HANSFORD, T. G., AND J. F. SPRINGgS II (2006): The Politics of Precedent on the US Supreme Court. Princeton, NJ: Princeton University Press.

Helmke, G. (2004): Courts under Constraints: Judges, Generals, and Presidents in Argentina. Cambridge: Cambridge University Press.

Hettinger, V. A., S. A. Lindquist, and W. L. Martinek (2003): "Separate Opinion Writing on the United States Courts of Appeals," American Politics Research, 31(3), 215-50.

Hilbink, L. (2007): Judges beyond Politics in Democracy and Dictatorship: Lessons from Chile. Cambridge: Cambridge University Press.

IARYCZOWER, M., P. T. SPILLER, AND M. TOMMASI (2002): “Judicial Independence in Unstable Environments, Argentina 1935-1998," American Journal of Political Science, 46, 699-716. (2006): “Judicial Lobbying: The Politics of Labor Law Constitutional Interpretation," American Political Science Review, 100, 1-13. 
JonEs, G. (1982): "Should Judges Be Politicians?: The English Experience," Indiana Law Journal, 57 (2), 211-233.

KAPISZEWSKI, D., AND M. M. TAYlor (2008): “Doing Courts Justice? Studying Judicial Politics in Latin America," Perspectives in Politics, 64, 741-67.

Keith, K. (2009): "The Interplay with the Judicial Committee of the Privy Council," in The Judicial House of Lords: 1876-2009, ed. by L. Blom-Cooper, G. Drewry, and B. Dickson, p. 315. Oxford University Press.

LAX, J. R., AND C. M. CAMERON (2007): "Bargaining and Opinion Assignment on the US Supreme Court," Journal of Law, Economics and Organization, 23, 276-302.

Le Sueur, A. (2001): "What is the future for the Judicial Committee of the Privy Council?," The Constitution Unit, UCL.

_ (2008): “A Report on Six Seminars About the UK Supreme Court," Queen Mary University of London, School of Law, Legal Studies Research Paper, 1.

Le Sueur, A. (2009): "From Appellate Committee to Supreme Court: A Narrative," in The Judicial House of Lords: 1876-2009, ed. by L. Blom-Cooper, G. Drewry, and B. Dickson. Oxford University Press.

LEE, J. (2009): “A Defence of Concurring Speeches," Public Law, pp. 305-331.

(ed.) (2011): From House of Lords to Supreme Court: Judges, Jurists and the Process of Judging. Hart Publishing Oxford.

LORD KERR OF TONAGHMORE (8 October 2012): "Dissenting judgments - self indulgence or self sacrifice?," The Birkenhead Lecture.

LORD NEUBERGER (2014): "The role of judges in human rights jurisprudence: a comparison of the Australian and UK experience," .

Malleson, K. (2009): "Appointments to the House of Lords: Who Goes Upstairs," in The Judicial House of Lords: 1876-2009, ed. by L. Blom-Cooper, G. Drewry, and B. Dickson. Oxford University Press. 
Massie, T., K. A. Randazzo, And D. R. Songer (2014): "The Politics of Judicial Retirement in Canada and the United Kingdom," Journal of Law and Courts, 2(2), 273-299.

Munday, R. (2002): "Judicial Configurations - Permutations of the Court and Properties of Judgment," Cambridga Law Journal, 61(3), 621-656.

NEUberGer, L. (2012): “No Judgment - No Justice,” First annual BAILII Lecture.

O’Neill, A. (2001): “Judicial Politics and the Judicial Committee: The Devolution Jurisprudence of the Privy Council," Modern Law Review, 64, 603-617.

O’NeILl, A. (2004): “Building the UK's New Supreme Court: National and Comparative Perspective," in Judging Democracy: the Devolutionary Settlement and the Scottish Constitution, ed. by A. Le Sueur. Oxford University Press.

Padovano, F. (2009): “The Time-Varying Independence of Italian Peak Judicial Institutions," Constitutional Political Economy, 20, 230-50.

Paterson, A. (2013): Final Judgment - The Last Law Lords and the Supreme Court. Hart Publishing.

Phillips, F. (2009): "Reflections from the New Commonwealth," in The Judicial House of Lords: 1876-2009, ed. by L. Blom-Cooper, G. Drewry, and B. Dickson, p. 376. Oxford University Press. Poole, T., And S. ShaH (2011): "The Law Lords and Human Rights," The Modern Law Review, 74 (1), 79-105.

Posner, R. A. (2011): “Realism About Judges," Northwestern University Law Review, 105, 57786.

RAmseyer, J. M., And E. B. RASmusen (2003): Measuring Judicial Independence: The Political Economy of Judging in Japan. Chicago: University of Chicago Press.

(2006): "The Case for Managed Judges: Learning from Japan after the Political Upheaval of 1993," University of Pennsylvania Law Review, 154, 1879-930.

RoBERTSON, D. (1982): "Judicial Ideology in the House of Lords: A Jurimetric Analysis," British Journal of Political Science, 12 (1), 1-25. 
SAlzberger, E., AND P. Fenn (1999): “Judicial Independence: Some Evidence from the English Court of Appeal," Journal of Law and Economics, 42, 831-847.

Schneider, M. R. (2005): “Judicial Career Incentives and Court Performance: An Empirical Study of the German Labour Courts of Appeal," European Journal of Law and Economics, 20, $127-44$.

SEgal, J. A., AND A. D. Cover (1989): "Ideological Values and the Votes of US Supreme Court Justices," American Political Science Review, 83, 557-65.

Segal, J. A., And H. J. Spaeth (2002): The Supreme Court and the Attitudinal Model Revisited. Cambridge: Cambridge University Press.

SHACHAR, Y., M. Gross, AND R. HARRIS (1997): “ Anatomy of Discourse and Dissent in the Supreme Court - Quantitative Analyses," Tel Aviv U. L. Rev., 20, 749-95.

SMYTH, R., AND P. K. NARAYAN (2004): "Hail to the Chief! Leadership and Structural Change in the Level of Consensus on the High Court of Australia," Journal of Empirical Legal Studies, 1, $399-427$.

Songer, D. R., J. SZMer, AND S. W. Johnson (2011): "Explaining Dissent on the Supreme Court of Canada," Canadian Journal of Political Science, 44, 389-409.

TAte, C. N., And P. Sittiwong (1989): "Decision Making in the Canadian Supreme Court: Extending the Personal Attributes Model Across Nations," Journal of Politics, 51, 900-16.

VAnberg, G. (2005): The Politics of Constitutional Review in Germany. Cambridge: Cambridge University Press.

Voigt, S., M. Ebeling, And L. Blume (2007): “Improving Credibility by Delegating Judicial Competence - The Case of the Judicial Committee of the Privy Council," Journal of Development Economics, 82, 348-373.

WALKER, N. (2010): Final Appellate Jurisdiction in the Scottish Legal System. The Scottish Government. 
Appendix 


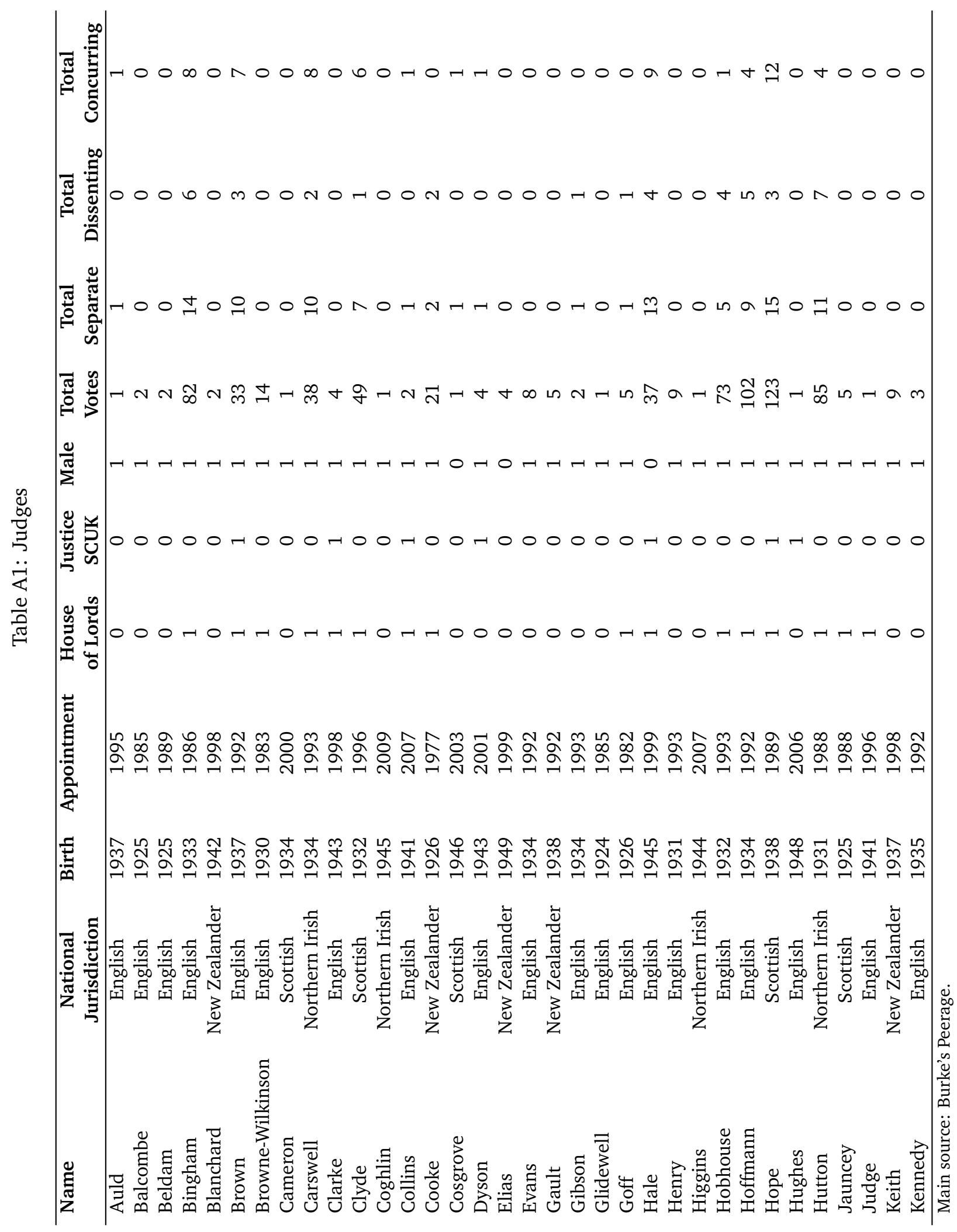




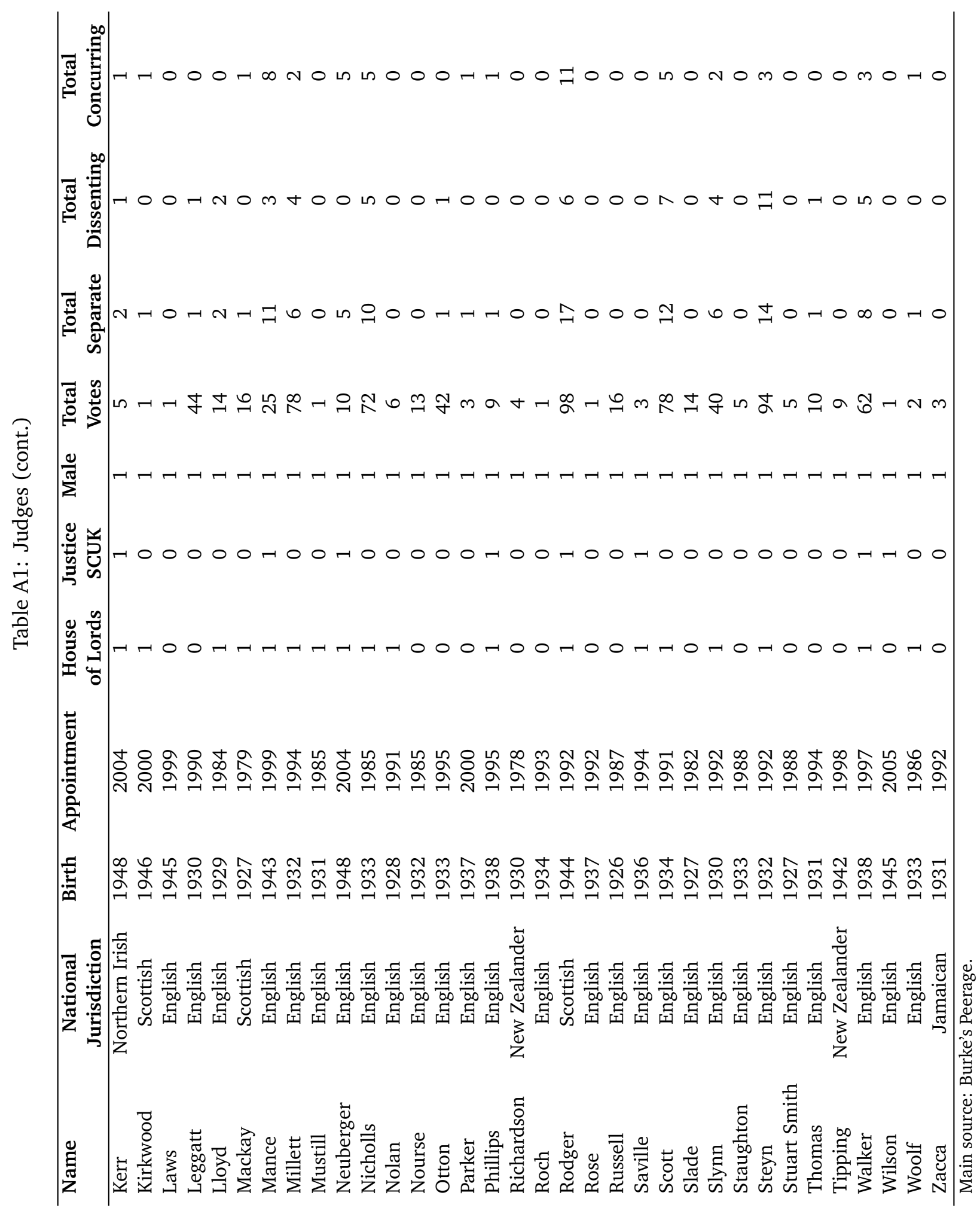


Table 9: Results for separate votes - std. errors clustered by author judge (excl. 2010 and 2011)

\begin{tabular}{|c|c|c|c|c|c|c|}
\hline & Reg 1 & Reg 2 & Reg 3 & $\operatorname{Reg} 4$ & Reg 5 & Reg 6 \\
\hline \multirow[t]{2}{*}{ Devolution } & $5.83 * * *$ & $6.41 * * *$ & $6.66 * * *$ & $6.33 * * *$ & $6.74 * * *$ & $7.02 * * *$ \\
\hline & $(0.00)$ & $(0.00)$ & $(0.00)$ & $(0.00)$ & $(0.00)$ & $(0.00)$ \\
\hline \multirow[t]{2}{*}{ Domestic } & -2.40 & -0.96 & -1.03 & $-2.73 *$ & -1.57 & -1.67 \\
\hline & $(0.11)$ & $(0.64)$ & $(0.62)$ & $(0.08)$ & $(0.44)$ & $(0.42)$ \\
\hline \multirow[t]{2}{*}{ Scottish judge } & $-0.66 * *$ & -0.56 & -0.56 & $-0.86 * *$ & -0.72 & -0.71 \\
\hline & $(0.03)$ & $(0.23)$ & $(0.23)$ & $(0.03)$ & $(0.18)$ & $(0.18)$ \\
\hline \multirow[t]{2}{*}{ Female judge } & -0.48 & -0.19 & -0.21 & -0.69 & -0.30 & -0.31 \\
\hline & $(0.33)$ & $(0.67)$ & $(0.63)$ & $(0.18)$ & $(0.53)$ & (0.49) \\
\hline \multirow[t]{2}{*}{ Law Lord judge } & $1.15^{* *}$ & $1.20 *$ & $1.22 \%$ & $1.27 * *$ & $1.30 *$ & $1.33^{*}$ \\
\hline & $(0.04)$ & $(0.06)$ & $(0.06)$ & (0.04) & $(0.06)$ & $(0.06)$ \\
\hline \multirow[t]{2}{*}{ Seniority } & -0.02 & -0.01 & -0.01 & -0.02 & -0.01 & -0.01 \\
\hline & $(0.42)$ & $(0.52)$ & $(0.58)$ & $(0.52)$ & $(0.69)$ & $(0.74)$ \\
\hline \multirow[t]{2}{*}{ Scottish author } & 0.26 & 0.32 & 0.21 & 0.38 & 0.33 & 0.21 \\
\hline & $(0.46)$ & $(0.36)$ & $(0.58)$ & $(0.30)$ & $(0.34)$ & $(0.55)$ \\
\hline \multirow[t]{2}{*}{ Sen. LL Bingham } & $3.21 * * *$ & $3.00 * * *$ & $3.08 * * *$ & $3.45 * * *$ & $3.14^{* * *}$ & $3.25 * * *$ \\
\hline & $(0.00)$ & $(0.00)$ & $(0.00)$ & $(0.00)$ & $(0.00)$ & $(0.00)$ \\
\hline \multirow[t]{2}{*}{ Business law } & -0.64 & -0.59 & -0.65 & -0.68 & -0.60 & -0.65 \\
\hline & $(0.46)$ & $(0.48)$ & $(0.41)$ & $(0.46)$ & $(0.48)$ & $(0.42)$ \\
\hline \multirow[t]{2}{*}{ Criminal } & 0.15 & -0.10 & -0.27 & 0.33 & -0.05 & -0.23 \\
\hline & $(0.74)$ & $(0.84)$ & $(0.55)$ & $(0.50)$ & $(0.91)$ & $(0.62)$ \\
\hline \multirow[t]{2}{*}{ Rights-Commonw. } & $0.80 * *$ & 0.39 & 0.29 & $0.99 * *$ & 0.43 & 0.32 \\
\hline & $(0.03)$ & $(0.28)$ & $(0.43)$ & $(0.02)$ & $(0.24)$ & (0.39) \\
\hline \multirow[t]{2}{*}{ Land and property } & -0.85 & -0.82 & -0.87 & -0.92 & -0.87 & -0.92 \\
\hline & (0.19) & $(0.17)$ & (0.19) & $(0.18)$ & $(0.15)$ & $(0.17)$ \\
\hline \multirow[t]{2}{*}{ Panel size } & & $0.75 * * *$ & $0.78 * * *$ & & $0.69 * * *$ & $0.72 * * *$ \\
\hline & & $(0.00)$ & $(0.00)$ & & $(0.00)$ & $(0.00)$ \\
\hline \multirow[t]{2}{*}{ Pro-appellant } & & -0.21 & -0.23 & & -0.23 & -0.24 \\
\hline & & (0.59) & $(0.55)$ & & $(0.56)$ & $(0.53)$ \\
\hline \multirow{2}{*}{ Judge is in majority } & & -0.06 & -0.06 & & 0.01 & 0.01 \\
\hline & & $(0.87)$ & $(0.87)$ & & $(0.97)$ & $(0.97)$ \\
\hline \multirow[t]{2}{*}{ Same jurisd. judge/case } & & -0.28 & -0.27 & & -0.41 & -0.40 \\
\hline & & $(0.48)$ & $(0.49)$ & & $(0.33)$ & $(0.35)$ \\
\hline \multirow[t]{2}{*}{ Same jurisd. judge/author judge } & & 0.26 & 0.25 & & 0.25 & 0.23 \\
\hline & & $(0.33)$ & $(0.36)$ & & $(0.41)$ & $(0.45)$ \\
\hline \multirow[t]{2}{*}{ Same jurisd. author judge/case } & & -0.66 & -0.87 & & -0.52 & -0.72 \\
\hline & & $(0.52)$ & $(0.43)$ & & $(0.60)$ & $(0.49)$ \\
\hline \multirow[t]{2}{*}{ Appellant individual } & & & 0.05 & & & 0.05 \\
\hline & & & $(0.88)$ & & & $(0.89)$ \\
\hline \multirow[t]{2}{*}{ Respondent individual } & & & -0.54 & & & -0.59 \\
\hline & & & $(0.37)$ & & & $(0.34)$ \\
\hline \multirow[t]{2}{*}{ Constant } & $-3.74 * * *$ & $-7.32 * * *$ & $-7.33 * * *$ & $-4.01 * * *$ & $-7.23 * * *$ & $-7.27 * * *$ \\
\hline & $(0.00)$ & $(0.00)$ & $(0.00)$ & $(0.00)$ & $(0.00)$ & $(0.00)$ \\
\hline Observations & 1,130 & 1,130 & 1,130 & 1,130 & 1,130 & 1,130 \\
\hline
\end{tabular}

Note: Robust $\mathrm{p}$-values in parentheses. ${ }^{*} \mathrm{p}<0.1,{ }^{* *} \mathrm{p}<0.05,{ }^{* * *} \mathrm{p}<0.01$. All regressions include year fixed effects. Regs. 1, 2 and 3 with weights for the probability of being sampled. Regs. 4, 5 and 6 with weights for the probability of being sampled and panel size. 
Table 10: Results for separate votes - std. errors clustered by judge (excl. 2010 and 2011)

\begin{tabular}{|c|c|c|c|c|c|c|}
\hline & Reg 1 & Reg 2 & Reg 3 & $\operatorname{Reg} 4$ & Reg 5 & Reg 6 \\
\hline Devolution & $\begin{array}{c}5.83^{* * * *} \\
(0.00)\end{array}$ & $\begin{array}{c}6.41 * * * \\
(0.00)\end{array}$ & $\begin{array}{c}6.66 * * * \\
(0.00)\end{array}$ & $\begin{array}{c}6.33^{* * * *} \\
(0.00)\end{array}$ & $\begin{array}{c}6.74 * * * \\
(0.00)\end{array}$ & $\begin{array}{c}7.02 * * * \\
(0.00)\end{array}$ \\
\hline Domestic & $\begin{array}{l}-2.40 * \\
(0.06)\end{array}$ & $\begin{array}{l}-0.96 \\
(0.54)\end{array}$ & $\begin{array}{l}-1.03 \\
(0.52)\end{array}$ & $\begin{array}{l}-2.73^{*} \\
(0.08)\end{array}$ & $\begin{array}{l}-1.57 \\
(0.44)\end{array}$ & $\begin{array}{l}-1.67 \\
(0.42)\end{array}$ \\
\hline Scottish judge & $\begin{array}{c}-0.66 * * * \\
(0.00)\end{array}$ & $\begin{array}{c}-0.56 * * * \\
(0.01)\end{array}$ & $\begin{array}{c}-0.56 * * * \\
(0.01)\end{array}$ & $\begin{array}{c}-0.86 * * \\
(0.03)\end{array}$ & $\begin{array}{l}-0.72 \\
(0.18)\end{array}$ & $\begin{array}{l}-0.71 \\
(0.18)\end{array}$ \\
\hline Female judge & $\begin{array}{l}-0.48 * \\
(0.07)\end{array}$ & $\begin{array}{l}-0.19 \\
(0.43)\end{array}$ & $\begin{array}{l}-0.21 \\
(0.39)\end{array}$ & $\begin{array}{l}-0.69 \\
(0.18)\end{array}$ & $\begin{array}{l}-0.30 \\
(0.53)\end{array}$ & $\begin{array}{l}-0.31 \\
(0.49)\end{array}$ \\
\hline Law Lord judge & $\begin{array}{c}1.15^{* * * *} \\
(0.00)\end{array}$ & $\begin{array}{c}1.20 * * * * \\
(0.00)\end{array}$ & $\begin{array}{c}1.22 * * * \\
(0.00)\end{array}$ & $\begin{array}{l}1.27 * * \\
(0.04)\end{array}$ & $\begin{array}{l}1.30 * \\
(0.06)\end{array}$ & $\begin{array}{l}1.33^{*} \\
(0.06)\end{array}$ \\
\hline Seniority & $\begin{array}{l}-0.02 \\
(0.46)\end{array}$ & $\begin{array}{l}-0.01 \\
(0.59)\end{array}$ & $\begin{array}{l}-0.01 \\
(0.61)\end{array}$ & $\begin{array}{l}-0.02 \\
(0.52)\end{array}$ & $\begin{array}{l}-0.01 \\
(0.69)\end{array}$ & $\begin{array}{l}-0.01 \\
(0.74)\end{array}$ \\
\hline Scottish author & $\begin{array}{c}0.26 \\
(0.42)\end{array}$ & $\begin{array}{c}0.32 \\
(0.44)\end{array}$ & $\begin{array}{c}0.21 \\
(0.61)\end{array}$ & $\begin{array}{c}0.38 \\
(0.30)\end{array}$ & $\begin{array}{c}0.33 \\
(0.34)\end{array}$ & $\begin{array}{c}0.21 \\
(0.55)\end{array}$ \\
\hline Sen. LL Bingham & $\begin{array}{c}3.21 \% * * \\
(0.00)\end{array}$ & $\begin{array}{c}3.00 * * * \\
(0.00)\end{array}$ & $\begin{array}{c}3.08 * * * \\
(0.00)\end{array}$ & $\begin{array}{c}3.45 * * * \\
(0.00)\end{array}$ & $\begin{array}{c}3.14 * * * \\
(0.00)\end{array}$ & $\begin{array}{c}3.25 * * * \\
(0.00)\end{array}$ \\
\hline Business law & $\begin{array}{l}-0.64 \\
(0.20)\end{array}$ & $\begin{array}{l}-0.59 \\
(0.20)\end{array}$ & $\begin{array}{l}-0.65 \\
(0.12)\end{array}$ & $\begin{array}{l}-0.68 \\
(0.46)\end{array}$ & $\begin{array}{l}-0.60 \\
(0.48)\end{array}$ & $\begin{array}{l}-0.65 \\
(0.42)\end{array}$ \\
\hline Criminal & $\begin{array}{c}0.15 \\
(0.75)\end{array}$ & $\begin{array}{l}-0.10 \\
(0.87)\end{array}$ & $\begin{array}{l}-0.27 \\
(0.63)\end{array}$ & $\begin{array}{c}0.33 \\
(0.50)\end{array}$ & $\begin{array}{l}-0.05 \\
(0.91)\end{array}$ & $\begin{array}{l}-0.23 \\
(0.62)\end{array}$ \\
\hline Rights-Commonw. & $\begin{array}{l}0.80 * * \\
(0.04)\end{array}$ & $\begin{array}{c}0.39 \\
(0.29)\end{array}$ & $\begin{array}{c}0.29 \\
(0.43)\end{array}$ & $\begin{array}{l}0.99 * * \\
(0.02)\end{array}$ & $\begin{array}{c}0.43 \\
(0.24)\end{array}$ & $\begin{array}{c}0.32 \\
(0.39)\end{array}$ \\
\hline Land and property & $\begin{array}{l}-0.85 * \\
(0.05)\end{array}$ & $\begin{array}{l}-0.82^{*} \\
(0.06)\end{array}$ & $\begin{array}{l}-0.87 * \\
(0.07)\end{array}$ & $\begin{array}{l}-0.92 \\
(0.18)\end{array}$ & $\begin{array}{l}-0.87 \\
(0.15)\end{array}$ & $\begin{array}{l}-0.92 \\
(0.17)\end{array}$ \\
\hline Panel size & & $\begin{array}{c}0.75^{* * * *} \\
(0.00)\end{array}$ & $\begin{array}{c}0.78 * * * \\
(0.00)\end{array}$ & & $\begin{array}{c}0.69 * * * * \\
(0.00)\end{array}$ & $\begin{array}{c}0.72 * * * \\
(0.00)\end{array}$ \\
\hline Pro-appellant & & $\begin{array}{l}-0.21 \\
(0.46)\end{array}$ & $\begin{array}{l}-0.23 \\
(0.42)\end{array}$ & & $\begin{array}{l}-0.23 \\
(0.56)\end{array}$ & $\begin{array}{l}-0.24 \\
(0.53)\end{array}$ \\
\hline Judge is in majority & & $\begin{array}{l}-0.06 \\
(0.86)\end{array}$ & $\begin{array}{l}-0.06 \\
(0.86)\end{array}$ & & $\begin{array}{c}0.01 \\
(0.97)\end{array}$ & $\begin{array}{c}0.01 \\
(0.97)\end{array}$ \\
\hline Same jurisd. judge/case & & $\begin{array}{l}-0.28 \\
(0.64)\end{array}$ & $\begin{array}{l}-0.27 \\
(0.64)\end{array}$ & & $\begin{array}{l}-0.41 \\
(0.33)\end{array}$ & $\begin{array}{l}-0.40 \\
(0.35)\end{array}$ \\
\hline Same jurisd. author judge/case & & $\begin{array}{l}-0.66 \\
(0.18)\end{array}$ & $\begin{array}{l}-0.87 \\
(0.15)\end{array}$ & & $\begin{array}{l}-0.52 \\
(0.60)\end{array}$ & $\begin{array}{l}-0.72 \\
(0.49)\end{array}$ \\
\hline Same jurisd. judge/author judge & & $\begin{array}{c}0.26 \\
(0.36)\end{array}$ & $\begin{array}{c}0.25 \\
(0.39)\end{array}$ & & $\begin{array}{c}0.25 \\
(0.41)\end{array}$ & $\begin{array}{c}0.23 \\
(0.45)\end{array}$ \\
\hline Appellant individual & & & $\begin{array}{c}0.05 \\
(0.85)\end{array}$ & & & $\begin{array}{c}0.05 \\
(0.89)\end{array}$ \\
\hline Respondent individual & & & $\begin{array}{l}-0.54 \\
(0.25)\end{array}$ & & & $\begin{array}{l}-0.59 \\
(0.34)\end{array}$ \\
\hline Constant & $\begin{array}{c}-3.74 * * * \\
(0.00)\end{array}$ & $\begin{array}{c}-7.32 * * * \\
(0.00)\end{array}$ & $\begin{array}{c}-7.33 * * * \\
(0.00)\end{array}$ & $\begin{array}{c}-4.01 \% * * \\
(0.00)\end{array}$ & $\begin{array}{c}-7.23 * * * \\
(0.00)\end{array}$ & $\begin{array}{c}-7.27^{* * * *} \\
(0.00)\end{array}$ \\
\hline Observations & 1,130 & 1,130 & 1,130 & 1,130 & 1,130 & 1,130 \\
\hline
\end{tabular}

Note: Robust $\mathrm{p}$-values by judge in parentheses. ${ }^{*} \mathrm{p}<0.1,{ }^{* *} \mathrm{p}<0.05$, ${ }^{* * *} \mathrm{p}<0.01$. All regressions include year fixed effects. Regs. 1, 2 and 3 with weights for the probability of being sampled. Regs. 4, 5 and 6 with weights for the probability of being sampled and panel size. 
Table 11: Results for separate votes - std. errors clustered by decision (excl. 2010 and 2011)

\begin{tabular}{|c|c|c|c|c|c|c|}
\hline & Reg 1 & Reg 2 & Reg 3 & $\operatorname{Reg} 4$ & Reg 5 & Reg 6 \\
\hline Devolution & $\begin{array}{c}5.83 * * * \\
(0.00)\end{array}$ & $\begin{array}{c}6.41 \% * * \\
(0.00)\end{array}$ & $\begin{array}{c}6.66^{* * * *} \\
(0.00)\end{array}$ & $\begin{array}{c}6.33^{* * * *} \\
(0.00)\end{array}$ & $\begin{array}{c}6.74 * * * \\
(0.00)\end{array}$ & $\begin{array}{c}7.02^{* * * *} \\
(0.00)\end{array}$ \\
\hline Domestic & $\begin{array}{l}-2.40 * \\
(0.08)\end{array}$ & $\begin{array}{l}-0.96 \\
(0.65)\end{array}$ & $\begin{array}{l}-1.03 \\
(0.63)\end{array}$ & $\begin{array}{l}-2.73^{*} \\
(0.05)\end{array}$ & $\begin{array}{l}-1.57 \\
(0.46)\end{array}$ & $\begin{array}{l}-1.67 \\
(0.45)\end{array}$ \\
\hline Scottish judge & $\begin{array}{c}-0.66^{* *} \\
(0.02)\end{array}$ & $\begin{array}{l}-0.56 \\
(0.13)\end{array}$ & $\begin{array}{l}-0.56 \\
(0.13)\end{array}$ & $\begin{array}{c}-0.86 * * * \\
(0.01)\end{array}$ & $\begin{array}{l}-0.72 \% \\
(0.08)\end{array}$ & $\begin{array}{l}-0.71 \% \\
(0.08)\end{array}$ \\
\hline Female judge & $\begin{array}{l}-0.48 \\
(0.33)\end{array}$ & $\begin{array}{l}-0.19 \\
(0.71)\end{array}$ & $\begin{array}{l}-0.21 \\
(0.67)\end{array}$ & $\begin{array}{l}-0.69 \\
(0.17)\end{array}$ & $\begin{array}{l}-0.30 \\
(0.56)\end{array}$ & $\begin{array}{c}-0.31 \\
(0.53)\end{array}$ \\
\hline Law Lord judge & $\begin{array}{l}1.15 * * \\
(0.01)\end{array}$ & $\begin{array}{l}1.20 * * \\
(0.02)\end{array}$ & $\begin{array}{l}1.22^{* * *} \\
(0.02)\end{array}$ & $\begin{array}{c}1.27^{* * * *} \\
(0.01)\end{array}$ & $\begin{array}{l}1.30 * * \\
(0.02)\end{array}$ & $\begin{array}{l}1.33 * * \\
(0.02)\end{array}$ \\
\hline Seniority & $\begin{array}{l}-0.02 \\
(0.47)\end{array}$ & $\begin{array}{l}-0.01 \\
(0.59)\end{array}$ & $\begin{array}{l}-0.01 \\
(0.61)\end{array}$ & $\begin{array}{l}-0.02 \\
(0.53)\end{array}$ & $\begin{array}{l}-0.01 \\
(0.72)\end{array}$ & $\begin{array}{l}-0.01 \\
(0.75)\end{array}$ \\
\hline Scottish author & $\begin{array}{c}0.26 \\
(0.58)\end{array}$ & $\begin{array}{c}0.32 \\
(0.53)\end{array}$ & $\begin{array}{c}0.21 \\
(0.71)\end{array}$ & $\begin{array}{c}0.38 \\
(0.39)\end{array}$ & $\begin{array}{c}0.33 \\
(0.49)\end{array}$ & $\begin{array}{c}0.21 \\
(0.67)\end{array}$ \\
\hline Sen. LL Bingham & $\begin{array}{c}3.21 * * * \\
(0.00)\end{array}$ & $\begin{array}{c}3.00 * * * \\
(0.00)\end{array}$ & $\begin{array}{c}3.08 * * * \\
(0.00)\end{array}$ & $\begin{array}{c}3.45 * * * \\
(0.00)\end{array}$ & $\begin{array}{c}3.14 * * * \\
(0.00)\end{array}$ & $\begin{array}{c}3.25 \% * * \\
(0.00)\end{array}$ \\
\hline Business law & $\begin{array}{l}-0.64 \\
(0.40)\end{array}$ & $\begin{array}{l}-0.59 \\
(0.43)\end{array}$ & $\begin{array}{l}-0.65 \\
(0.36)\end{array}$ & $\begin{array}{l}-0.68 \\
(0.38)\end{array}$ & $\begin{array}{l}-0.60 \\
(0.42)\end{array}$ & $\begin{array}{l}-0.65 \\
(0.36)\end{array}$ \\
\hline Criminal & $\begin{array}{c}0.15 \\
(0.76)\end{array}$ & $\begin{array}{l}-0.10 \\
(0.86)\end{array}$ & $\begin{array}{l}-0.27 \\
(0.64)\end{array}$ & $\begin{array}{c}0.33 \\
(0.53)\end{array}$ & $\begin{array}{l}-0.05 \\
(0.93)\end{array}$ & $\begin{array}{l}-0.23 \\
(0.69)\end{array}$ \\
\hline Rights-Commonw. & $\begin{array}{l}0.80 * \\
(0.07)\end{array}$ & $\begin{array}{c}0.39 \\
(0.40)\end{array}$ & $\begin{array}{c}0.29 \\
(0.54)\end{array}$ & $\begin{array}{l}0.99 * * \\
(0.03)\end{array}$ & $\begin{array}{c}0.43 \\
(0.35)\end{array}$ & $\begin{array}{c}0.32 \\
(0.50)\end{array}$ \\
\hline Land and property & $\begin{array}{l}-0.85 \\
(0.20)\end{array}$ & $\begin{array}{l}-0.82 \\
(0.20)\end{array}$ & $\begin{array}{l}-0.87 \\
(0.22)\end{array}$ & $\begin{array}{l}-0.92 \\
(0.18)\end{array}$ & $\begin{array}{l}-0.87 \\
(0.18)\end{array}$ & $\begin{array}{l}-0.92 \\
(0.21)\end{array}$ \\
\hline Panel size & & $\begin{array}{c}0.75 * * * \\
(0.00)\end{array}$ & $\begin{array}{c}0.78 * * * \\
(0.00)\end{array}$ & & $\begin{array}{c}0.69 * * * \\
(0.00)\end{array}$ & $\begin{array}{c}0.72 \% * * \\
(0.00)\end{array}$ \\
\hline Pro-appellant & & $\begin{array}{l}-0.21 \\
(0.56)\end{array}$ & $\begin{array}{l}-0.23 \\
(0.53)\end{array}$ & & $\begin{array}{l}-0.23 \\
(0.53)\end{array}$ & $\begin{array}{l}-0.24 \\
(0.50)\end{array}$ \\
\hline Judge is in majority & & $\begin{array}{l}-0.06 \\
(0.88)\end{array}$ & $\begin{array}{l}-0.06 \\
(0.88)\end{array}$ & & $\begin{array}{c}0.01 \\
(0.97)\end{array}$ & $\begin{array}{c}0.01 \\
(0.97)\end{array}$ \\
\hline Same jurisd. judge/case & & $\begin{array}{l}-0.28 \\
(0.65)\end{array}$ & $\begin{array}{l}-0.27 \\
(0.66)\end{array}$ & & $\begin{array}{l}-0.41 \\
(0.53)\end{array}$ & $\begin{array}{l}-0.40 \\
(0.54)\end{array}$ \\
\hline Same jurisd. author judge/case & & $\begin{array}{l}-0.66 \\
(0.56)\end{array}$ & $\begin{array}{l}-0.87 \\
(0.47)\end{array}$ & & $\begin{array}{l}-0.52 \\
(0.64)\end{array}$ & $\begin{array}{l}-0.72 \\
(0.54)\end{array}$ \\
\hline Same jurisd. judge/author judge & & $\begin{array}{c}0.26 \\
(0.37)\end{array}$ & $\begin{array}{c}0.25 \\
(0.40)\end{array}$ & & $\begin{array}{c}0.25 \\
(0.43)\end{array}$ & $\begin{array}{c}0.23 \\
(0.46)\end{array}$ \\
\hline Appellant individual & & & $\begin{array}{c}0.05 \\
(0.90)\end{array}$ & & & $\begin{array}{c}0.05 \\
(0.91)\end{array}$ \\
\hline Respondent individual & & & $\begin{array}{l}-0.54 \\
(0.31)\end{array}$ & & & $\begin{array}{l}-0.59 \\
(0.28)\end{array}$ \\
\hline Constant & $\begin{array}{c}-3.74 * * * * \\
(0.00)\end{array}$ & $\begin{array}{c}-7.32 * * * * \\
(0.00)\end{array}$ & $\begin{array}{c}-7.33 * * * \\
(0.00)\end{array}$ & $\begin{array}{c}-4.01 * * * \\
(0.00)\end{array}$ & $\begin{array}{c}-7.23 * * * * \\
(0.00)\end{array}$ & $\begin{array}{c}-7.27 * * * * \\
(0.00)\end{array}$ \\
\hline Observations & 1,130 & 1,130 & 1,130 & 1,130 & 1,130 & 1,130 \\
\hline
\end{tabular}

Note: Robust $\mathrm{p}$-values by decision in parentheses. ${ }^{*} \mathrm{p}<0.1,{ }^{* *} \mathrm{p}<0.05$, $* * * \mathrm{p}<0.01$. All regressions include year fixed effects. Regs. 1, 2 and 3 with weights for the probability of being sampled. Regs. 4, 5 and 6 with weights for the probability of being sampled and panel size. 
Table 12: Results for proportion of separate votes (excl. 2010 and 2011)

\begin{tabular}{|c|c|c|c|c|c|c|}
\hline & Reg 1 & Reg 2 & Reg 3 & $\operatorname{Reg} 4$ & Reg 5 & $\operatorname{Reg} 6$ \\
\hline \multirow[t]{2}{*}{ Devolution } & $4.23 * * *$ & $3.76 * * *$ & $3.77 * * *$ & $4.23 * * *$ & $3.76 * * *$ & $3.77 * *$ \\
\hline & $(0.00)$ & $(0.01)$ & $(0.01)$ & $(0.00)$ & $(0.01)$ & $(0.01)$ \\
\hline \multirow[t]{2}{*}{ Domestic } & $-2.38 *$ & -3.08 & -3.10 & $-2.38^{*}$ & -3.08 & -3.10 \\
\hline & $(0.05)$ & $(0.24)$ & $(0.24)$ & $(0.06)$ & $(0.29)$ & $(0.29)$ \\
\hline \multirow[t]{2}{*}{ Total Scottish } & -0.23 & -0.27 & -0.27 & -0.23 & -0.27 & -0.27 \\
\hline & $(0.32)$ & $(0.30)$ & $(0.31)$ & $(0.16)$ & $(0.25)$ & $(0.28)$ \\
\hline \multirow[t]{2}{*}{ Total female } & -0.13 & -0.22 & -0.23 & -0.13 & -0.22 & -0.23 \\
\hline & $(0.74)$ & $(0.56)$ & $(0.56)$ & $(0.77)$ & $(0.60)$ & $(0.61)$ \\
\hline \multirow[t]{2}{*}{ Total Law Lords } & $0.54 * * *$ & $0.47 * *$ & $0.47 * *$ & $0.54 * * *$ & $0.47 *$ & $0.47 *$ \\
\hline & $(0.00)$ & $(0.02)$ & $(0.03)$ & $(0.00)$ & $(0.05)$ & $(0.05)$ \\
\hline \multirow[t]{2}{*}{ Avg Sen. Years(Panel) } & -0.16 & -0.18 & -0.18 & -0.16 & $-0.18 *$ & $-0.18 *$ \\
\hline & $(0.23)$ & $(0.17)$ & $(0.17)$ & $(0.13)$ & $(0.06)$ & $(0.07)$ \\
\hline \multirow[t]{2}{*}{ Scottish author } & 0.04 & 0.75 & 0.73 & 0.04 & 0.75 & 0.73 \\
\hline & $(0.94)$ & $(0.22)$ & $(0.24)$ & $(0.91)$ & $(0.14)$ & $(0.17)$ \\
\hline \multirow[t]{2}{*}{ Sen. LL Bingham } & $2.21 * * *$ & $2.28 * *$ & $2.28 * *$ & $2.21 * * *$ & $2.28 * * *$ & $2.28 * * *$ \\
\hline & $(0.01)$ & $(0.01)$ & $(0.01)$ & $(0.00)$ & $(0.00)$ & $(0.00)$ \\
\hline \multirow{2}{*}{ Business law } & -0.42 & -0.44 & -0.43 & -0.42 & -0.44 & -0.43 \\
\hline & $(0.48)$ & $(0.47)$ & $(0.48)$ & $(0.53)$ & $(0.52)$ & $(0.52)$ \\
\hline \multirow[t]{2}{*}{ Criminal } & -0.18 & -0.17 & -0.20 & -0.18 & -0.17 & -0.20 \\
\hline & $(0.67)$ & $(0.71)$ & $(0.66)$ & $(0.63)$ & $(0.67)$ & $(0.61)$ \\
\hline \multirow[t]{2}{*}{ Rights-Commonw. } & 0.35 & 0.39 & 0.36 & 0.35 & 0.39 & 0.36 \\
\hline & $(0.34)$ & $(0.28)$ & $(0.34)$ & $(0.21)$ & $(0.16)$ & $(0.24)$ \\
\hline \multirow[t]{2}{*}{ Land and property } & -0.65 & -0.71 & -0.70 & -0.65 & -0.71 & -0.70 \\
\hline & $(0.31)$ & $(0.24)$ & $(0.27)$ & $(0.22)$ & $(0.15)$ & $(0.17)$ \\
\hline \multirow{2}{*}{ Pro-appellant } & & -0.14 & -0.14 & & -0.14 & -0.14 \\
\hline & & $(0.61)$ & $(0.62)$ & & $(0.65)$ & $(0.64)$ \\
\hline \multirow{2}{*}{ Total judges in majority } & & -0.18 & -0.18 & & -0.18 & -0.18 \\
\hline & & $(0.19)$ & $(0.19)$ & & $(0.17)$ & $(0.17)$ \\
\hline \multirow[t]{2}{*}{ Total same jurisd. judge/case } & & 0.45 & 0.46 & & 0.45 & 0.46 \\
\hline & & $(0.27)$ & $(0.27)$ & & $(0.39)$ & $(0.38)$ \\
\hline \multirow[t]{2}{*}{ Total same jurisd. judge/author judge } & & $0.29 *$ & $0.29 *$ & & $0.29 *$ & $0.29 *$ \\
\hline & & $(0.06)$ & $(0.06)$ & & $(0.05)$ & $(0.05)$ \\
\hline \multirow[t]{2}{*}{ Same jurisd. author judge/case } & & -0.94 & -0.98 & & -0.94 & -0.98 \\
\hline & & $(0.45)$ & $(0.43)$ & & $(0.42)$ & $(0.40)$ \\
\hline \multirow[t]{2}{*}{ Appellant individual } & & & 0.06 & & & 0.06 \\
\hline & & & $(0.87)$ & & & $(0.83)$ \\
\hline \multirow[t]{2}{*}{ Respondent individual } & & & -0.06 & & & -0.06 \\
\hline & & & $(0.88)$ & & & $(0.89)$ \\
\hline \multirow[t]{2}{*}{ Constant } & $-2.44^{*}$ & $-2.18^{*}$ & $-2.23 *$ & -2.44 & $-2.18 *$ & $-2.23 * *$ \\
\hline & $(0.06)$ & $(0.08)$ & $(0.08)$ & $(0.10)$ & $(0.07)$ & $(0.05)$ \\
\hline Observations & 331 & 331 & 331 & 331 & 331 & 331 \\
\hline
\end{tabular}

Note: Regs. 1-3 with robust standard errors; Regs. 4-6 with clustered standard errors by author judge. $* \mathrm{p}<0.1, * *$ $\mathrm{p}<0.05, * * * \mathrm{p}<0.01$. 